\title{
CREST in the Nucleus Accumbens Core Regulates Cocaine Conditioned Place Preference, Cocaine-Seeking Behavior, and Synaptic Plasticity
}

\author{
Yasaman Alaghband, ${ }^{1,2,4}$ Enikö Kramár, ${ }^{1,4}$ ๑ Janine L. Kwapis, ${ }^{1,3,4}$ @Earnest S. Kim, ${ }^{5}$ Thekla J. Hemstedt, ${ }^{1,4}$ \\ Alberto J. López, ${ }^{1,2,4}$ André 0. White, ${ }^{1,2,4}$ Amni Al-Kachak, ${ }^{1,4}$ Cosasumwen V. Aimiuwu, ${ }^{1,4}$ Kasuni K. Bodinayake, ${ }^{1,4}$ \\ Nicole C. Oparaugo, ${ }^{1,4}$ Joseph Han, ${ }^{1,4}$ K. Matthew Lattal, ${ }^{5}$ and Marcelo A. Wood ${ }^{1,2,3,4}$ \\ ${ }^{1}$ Department of Neurobiology and Behavior, Center for the Neurobiology of Learning and Memory, ${ }^{2}$ Irvine Center for Addiction Neuroscience, ${ }^{3}$ Institute for \\ Memory Impairments and Neurological Disorders, University of California, Irvine, Irvine, California 92697, ${ }^{4}$ Center for the Neurobiology of Learning and \\ Memory, Irvine, California, 92697, and 5Department of Behavioral Neuroscience, Oregon Health \& Science University, Portland, Oregon 97239
}

Epigenetic mechanisms result in persistent changes at the cellular level that can lead to long-lasting behavioral adaptations. Nucleosome remodeling is a major epigenetic mechanism that has not been well explored with regards to drug-seeking behaviors. Nucleosome remodeling is performed by multi-subunit complexes that interact with DNA or chromatin structure and possess an ATP-dependent enzyme to disrupt nucleosome-DNA contacts and ultimately regulate gene expression. Calcium responsive transactivator (CREST) is a transcriptional activator that interacts with enzymes involved in both histone acetylation and nucleosome remodeling. Here, we examined the effects of knocking down CREST in the nucleus accumbens (NAc) core on drug-seeking behavior and synaptic plasticity in male mice as well as drug-seeking in male rats. Knocking down CREST in the NAc core results in impaired cocaine-induced conditioned place preference (CPP) as well as theta-induced long-term potentiation in the NAc core. Further, similar to the CPP findings, using a selfadministration procedure, we found that CREST knockdown in the NAc core of male rats had no effect on instrumental responding for cocaine itself on a first-order schedule, but did significantly attenuate responding on a second-order chain schedule, in which responding has a weaker association with cocaine. Together, these results suggest that CREST in the NAc core is required for cocaine-induced CPP, synaptic plasticity, as well as cocaine-seeking behavior.

Key words: cocaine; CREST; epigenetics; LTP; nucleosome remodeling; nucleus accumbens

\section{Significance Statement}

This study demonstrates a key role for the role of Calcium responsive transactivator (CREST), a transcriptional activator, in the nucleus accumbens (NAc) core with regard to cocaine-induced conditioned place preference (CPP), self-administration (SA), and synaptic plasticity. CREST is a unique transcriptional regulator that can recruit enzymes from two different major epigenetic mechanisms: histone acetylation and nucleosome remodeling. In this study we also found that the level of potentiation in the NAc core correlated with whether or not animals formed a CPP. Together the results indicate that CREST is a key downstream regulator of cocaine action in the NAc.

\section{Introduction}

Drug addiction is a complex, relapsing disorder wherein compulsive drug-seeking and drug-taking behavior persist despite aver-

Received Oct. 9, 2017; revised Aug. 29, 2018; accepted Sept. 6, 2018.

Author contributions: Y.A., E.K., J.L.K., E.S.K., K.M.L., and M.A.W. designed research; Y.A., E.K., J.L.K., E.S.K., T.J.H., A.J.L., A.O.W., A.A.-K., O.V.A., K.K.B., N.C.O., and J.H. performed research; Y.A., E.K., E.S.K., and K.M.L. analyzed data; Y.A., E.K., E.S.K., K.M.L., and M.A.W. wrote the paper.

This work was supported by the National Institute on Drug Abuse Grant (DA025922) to K.M.L. and M.A.W., the National Institute of Mental Health Grant (MH101491) to M.A.W., and National Institute on Drug Abuse and National Institute on Aging Grants (F32 DA043998 and T32 AG000096-33) to Y.A. We thank Evan Jeffries and Kay Linker for critical feedback on the paper. sive consequences (Kalivas and Volkow, 2005; Hyman et al., 2006). Extensive drug-use leads to changes in the CNS that ultimately results in tolerance, physical dependence, sensitization, craving, and relapse. At a molecular level, epigenetic regulation of chromatin (the protein complex that packages genomic DNA), by histone acetylation or nucleosome remodeling, has been

\section{The authors declare no competing financial interests.}

Correspondence should be addressed to Marcelo A. Wood, Department of Neurobiology and Behavior, Center for the Neurobiology of Learning and Memory, 2205 McGaugh Hall, Irvine, CA 92697. E-mail: mwood@uci.edu.

A.0. White's present address: Department of Biological Sciences, Mount Holyoke College, South Hadley, MA 01075 . 
shown to cause stable changes in cell function and may underlie the onset and persistence of drug-seeking behavior. Histone acetylation is promoted by histone acetyltransferases and inhibited by histone deacetylases, which in general facilitate and repress gene expression, respectively (Jenuwein and Allis, 2001; Kouzarides, 2007; Yacubian et al., 2007). Nucleosome remodeling is performed by multi-subunit complexes that use ATP hydrolysis to disrupt nucleosome-DNA contacts by sliding, evicting, or exchanging nucleosomes (Hargreaves and Crabtree, 2011). Calcium responsive transactivator (CREST) is a unique transcriptional activator that directly interacts with enzymes involved in both histone acetylation and nucleosome remodeling. Thus, CREST lies at a key point of intersection between these two epigenetic mechanisms that may be critical for the long-term effects of cocaine on neural plasticity and behavior.

CREST has been shown to regulate gene expression following calcium influx induced by neuronal depolarization (Aizawa et al., 2004; Qiu and Ghosh, 2008). The mechanism by which CREST regulates transcription may largely be due to its protein-protein interacting partners. The CREST C-terminus interacts with the histone acetyltransferase CREB-binding protein (CBP; Aizawa et al., 2004), whereas the N-terminus interacts with the ATPase Brahma-related gene 1 (BRG1; Qiu and Ghosh, 2008). CBP and histone acetylation have been implicated in cocaine action by several studies (Levine et al., 2005; Kumar et al., 2005; Renthal et al., 2007, 2009), including one examining the effect of a focal deletion of CBP in the nucleus accumbens (NAc; Malvaez et al., 2011). BRG1 is one of the main ATPases in the nucleosome remodeling complex called nBAF (neuronal BRG1 associated factors). To date, little is known about the role of nucleosome remodeling and cocaine action. During chronic cocaine conditions, BRG1 is present at the Cdk5 gene promoter (Kumar et al., 2005). Recently, we demonstrated that a neuron-specific subunit of $\mathrm{nBAF}$, called BAF53b, is required for cocaine-induced conditioned place preference (CPP) and long-term potentiation (LTP) in the NAc (White et al., 2016). Together, the findings above lead to the idea that CREST may be a keystone transcriptional regulator that coordinates histone acetylation and nucleosome remodeling during cocaine-dependent calcium signaling.

CREST is one of the 15 identified subunits of the nBAF complex (Staahl et al., 2013). SS18, the paralog of CREST, is found in neuronal progenitor BAF complexes (npBAF) and a switch from SS18 to CREST, which is required for neuronal progenitors to differentiate into postmitotic neurons, is mediated by a miRNAdependent mechanism during embryonic development (Staahl et al., 2013). nBAF and its subunits are involved in dendritic morphogenesis and activity-dependent dendritic outgrowth (Parrish et al., 2006; Wu et al., 2007) as well as long-term memory and LTP (Vogel-Ciernia et al., 2013, 2017). These findings suggest that CREST may have a pivotal role in synaptic plasticity and cocaineinduced effects on behavior. Therefore, in the current study, we examined the role of CREST in the nucleus accumbens in cocaine CPP, cocaine-seeking, as well as LTP, a cellular mechanism thought to underlie memory processes.

A. Al-Kachak's present address: Department of Neuroscience, I cahn School of Medicine, Mount Sinai, New York, NY 10029.

0.V. Aimiuwu's present address: Department of Genetics and Development, Columbia University College of Physicians and Surgeons, New York, NY 10032

DOI:10.1523/JNEUROSCI.2911-17.2018

Copyright $\odot 2018$ the authors $\quad 0270-6474 / 18 / 389515-13 \$ 15.00 / 0$

\section{Materials and Methods}

\section{Subjects}

All procedures were approved by the Institutional Animal Care and Use Committees of University of California, Irvine or Oregon Health and Science University and were in compliance with the National Institutes of Health guidelines. Subjects were adult male 8- to 12-week-old C57BL/6 mice and Long-Evans rats. Rats were food restricted to maintain body weight throughout self-administration; mice had access to food and water ad libitum in their home cages with lights maintained on a $12 \mathrm{~h}$ light/dark cycle. Behavioral testing was performed during the light portion of the cycle for mice and during the dark cycle for rats.

\section{Surgical procedures}

Mice or rats were anesthetized with $4 \%$ isoflurane in oxygen and maintained at $1.5-2.0 \%$ for the duration of surgery. Mice received morpholino or small interfering RNAs (siRNAs; $0.5 \mu \mathrm{l}$ ) bilaterally at a rate of 6 $\mu \mathrm{l} / \mathrm{h}$ via an infusion needle positioned in the NAc core [anteroposterior (AP): $+1.3 \mathrm{~mm}$; mediolateral (ML): $\pm 1.1 \mathrm{~mm}$; dorsoventral (DV): -4.5 mm relative to bregma (Paxinos and Franklin, 2001)]. Morpholino or siRNA were infused with dual 28 gauge infusers $(2.2 \mathrm{~mm}$ center-tocenter) attached to PE50 tubing and connected to Hamilton syringes mounted on infusion pumps. Rats received $0.5 \mu \mathrm{l}$ of either Scrambled morpholino or anti-CREST morpholino into the Nac core (AP: $1.2 \mathrm{~mm}$, ML: $\pm 1.8 \mathrm{~mm}, \mathrm{DV}: 6.1 \mathrm{~mm}$ relative to bregma (Paxinos and Watson, $2007)$ at a rate of $6 \mu \mathrm{l} / \mathrm{h}$. Rats were given $5-7 \mathrm{~d}$ to recover and were given ad libitum food and water. After 5-7 d, animals were implanted with a chronic intravenous catheter as previously described (Pizzimenti et al., 2017).

\section{siRNA and morpholino}

For the CREST knockdown experiments using the siRNAs approach, a set of four Accell siRNAs (Dharmacon) targeted against CREST were prepared at a final concentration of $5 \mu \mathrm{M}$ total siRNA before injection. Intra-NAc core infusion of siRNA targeting CREST (anti-CREST siRNA) or Accell nontargeting control pool (Control siRNA) were performed using the infusion procedure described above. These siRNAs are formulated for direct in vivo delivery and the carrier is JetSI (a mixture of cationic lipids; Macks and Lee, 2016). A time course experiment was conducted to confirm siRNA knockdown spanning the days during which cocaine $\mathrm{CPP}$ conditioning were conducted. For the time course experiment, animals received nontargeting control siRNA in the NAc core of one hemisphere and anti-CREST siRNA in the NAc core of the other hemisphere such that each animal served as its own control. CREST knockdown was quantified across Days 2-6 postinfusion.

For the CREST knockdown experiments using the morpholino approach, Vivo-Morpholino targeting CREST (Gene Tools) was prepared at a final concentration of $2 \mu \mathrm{m}$ before injection. Morpholino oligonucleotides are stable, uncharged, water-soluble molecules used to block complementary sequences of RNA, preventing processing, read through, or protein binding at those sites (Moulton, 2007). They are delivered via Nucleofection (www.amaxa.com). Animals received Scrambled morpholino control ("Control morpholino") in the NAc core of one hemisphere and morpholino targeting CREST ("anti-CREST morpholino") in the NAc core of the other hemisphere such that each animal served as its own control. CREST knockdown was quantified 2 and $6 \mathrm{~d}$ postinfusion. Because they are thought to be more stable and long-lasting than siRNAs (Moulton, 2017), we also confirmed knockdown at the end of behavior experiments. Immunohistochemistry and Western blots were used to confirm morpholino knockdown and failure to see knockdown was used as criteria for excluding animals from those experimental groups.

\section{Drugs}

Cocaine- $\mathrm{HCl}$ was purchased from Sigma-Aldrich and dissolved in saline $(0.9 \% \mathrm{NaCl})$. Cocaine- $\mathrm{HCl}$ is expressed as the weight of the salt. For experiments in which a final dose of $5 \mathrm{mg} / \mathrm{kg}$ cocaine- $\mathrm{HCl}$ was used, cocaine- $\mathrm{HCl}$ was dissolved to a final concentration of $0.5 \mathrm{mg} / \mathrm{ml}$ and administered in a volume of $10 \mathrm{ml} / \mathrm{kg}$ body weight. For experiments in which a final dose of $10 \mathrm{mg} / \mathrm{kg}$ cocaine- $\mathrm{HCl}$ was used, cocaine- $\mathrm{HCl}$ was dissolved to a final concentration of $1 \mathrm{mg} / \mathrm{ml}$ and administered in a 
volume of $10 \mathrm{ml} / \mathrm{kg}$ body weight. Cocaine- $\mathrm{HCl}$ and saline were administered intraperitoneally.

\section{Immunofluorescence}

Mice or rats were killed by cervical dislocation and their brains were removed and flash-frozen in ice-cold isopentane. Twenty micrometer slices were collected throughout the amygdala or dorsal hippocampus, thaw-mounted on slides, and stored at $-80^{\circ} \mathrm{C}$ until use. Slides were fixed with $4 \%$ paraformaldehyde for $10 \mathrm{~min}$ and permeabilized in $0.01 \%$ Triton X-100 in 0.1 m PBS for 15 min. Slides were then blocked for $1 \mathrm{~h}$ at room temperature in $8 \%$ normal goat serum (Jackson ImmunoResearch), and incubated overnight at $4^{\circ} \mathrm{C}$ in primary antibody (CREST antibody: 1:500; Proteintech 12439-1-AP, NeuroTrace: 1:50). The following day, slides were incubated for $1 \mathrm{~h}$ at room temperature with anti-rabbit AlexaFluor 555 (1:1000 dilution; Cell Signaling Technology) in the dark followed by either a 15 min DAPI incubation (1:10,000; Invitrogen). Slides were coverslipped using VECTASHIELD Antifade mounting medium (Vector Laboratories).

For the immunohistochemistry quantification, treatment groups were represented on each slide and all images on a slide were captured using a Zeiss LSM700 confocal microscope with the same exposure time. Immunolabeling was quantified with NIH ImageJ software by sampling the optical density of immunofluorescence in the NAc core and normalizing to background. In addition, all quantifications were normalized to control animals set at $100 \%$.

\section{Quantitative RT-PCR}

Quantitative real-time RT-PCR was performed to measure CREST expression following one-trial cocaine conditioning as previously described (López et al., 2016; White et al., 2016; Alaghband et al., 2017; Kwapis et al., 2017). Punches $(0.5 \mathrm{~mm})$ in the NAc were collected from $500 \mu \mathrm{m}$ slices. All tissue was stored at $-80^{\circ} \mathrm{C}$ until processing.

RNA was isolated using an RNeasy Minikit (Qiagen) and cDNA was created using the Transcriptor First Strand cDNA Synthesis kit (Roche Applied Science). The following primers were used, derived from the Roche Universal ProbeLibrary: CREST forward primer, $5^{\prime}$-gaccaacatcaacatgcagtct-3'; CREST reverse primer, $5^{\prime}$-gctgagttgtagtgggacgtg- $3^{\prime}$; cagcaggc (probe 40; Roche). Hypoxanthine phosphoribosyltransferase (HPRT5) was used as a reference gene for all RT-qPCR assays. For HPRT5, we used the following primers: forward primer, $5^{\prime}$-tgctcgagatgtcatgaagg- $3^{\prime}$; reverse primer, $5^{\prime}$-cttttatgtcccccgttgac- $3^{\prime}$; probe,/5HEX/atcacattgtggccctctgt/3BHQ_1/. The non-overlapping dyes and quencher on the reference gene allow for multiplexing in the Roche LightCycle 480 II machine (Roche Applied Science). All values were normalized to HPRT5 expression levels. Analysis and statistics were performed using the Roche proprietary algorithms and REST 2009 software based on the Pfaffl method (Pfaffl, 2001; Pfaffl et al., 2002). Quantifications were normalized to Saline controls set at $100 \%$.

\section{Western blot analysis}

Mice and rats were killed by cervical dislocation and their brains were removed and flash-frozen in ice-cold isopentane. $1 \mathrm{~mm}$ punches in the NAc core of mice and rats were collected from $500 \mu \mathrm{m}$ slices. Protein was isolated by homogenization on ice in tissue protein extraction reagent (T-PER; ThermoFisher Scientific) in the presence of protease and phosphatase inhibitors. The final protein concentration was determined using the Bio-Rad protein assay bovine serum albumin standards. Tissue samples were prepared in a standard $5 \times$ SDS/PAGE sample buffer ( $1 \mathrm{M}$ Tris, $\mathrm{pH} 6.8,20 \% \mathrm{v} / \mathrm{v}$ glycerol, $10 \% \mathrm{w} / \mathrm{v}$ SDS, $0.05 \%$ bromophenol blue, and $10 \mathrm{~mm} 2-\beta$-mercapto-ethanol). Ten micrograms of protein were loaded per well and run at $200 \mathrm{~V}$ for $50 \mathrm{~min}$ on NuPage $10 \%$ Bis-Tris polyacrylamide gels (Invitrogen). Electrophoretic transfer was then performed overnight at $15 \mathrm{~V}$ at $4^{\circ} \mathrm{C}$ onto polyvinylidene difluoride membrane. Membranes were blocked for $1 \mathrm{~h}$ at room temperature in blocking solution (TBS Tween 20 Starting Block; ThermoFisher Scientific) and then incubated in primary antibodies (1:1000 rabbit anti-CREST, Proteintech, 12439-1-AP; 1:1000 rabbit anti-GAPDH, Santa Cruz Biotechnology) with agitation for $1 \mathrm{~h}$ at room temperature. Membranes were then rinsed three times for 5 min each in PBS with agitation. Membranes were subsequently incubated in secondary antibody (1:5000 mouse anti- rabbit HRP light chain). Supersignal Westpico Chemiluminescent substrate (ThermoFisher Scientific) was used for chemiluminescent detection according to the manufacturer's instructions and analyzed using NIH ImageJ software. For Western blot analysis, band intensity for CREST protein was normalized to that of GAPDH, which served as the protein loading control. In addition, all quantifications were normalized to control animals set at $100 \%$.

\section{Conditioned place preference}

Apparatus. Place preference conditioning was performed as described previously in our studies (Malvaez et al., 2011; Rogge et al., 2013; White et al., 2016; Alaghband et al., 2017). Conditioning took place in a threechamber apparatus consisting of two larger compartments $(49.5 \times 13.7$ $\mathrm{cm})$ separated by a smaller compartment $(18.3 \times 13.7 \mathrm{~cm})$. The two larger compartments differed in visual, olfactory, and tactile cues. One compartment had white walls and a bar floor above pine shavings, whereas the other compartment had black and white checkered walls and a wire mesh floor above cedar shavings. The middle compartment had a solid polyvinyl floor. Additionally, this middle compartment had a white wall and a checkered wall leading into the corresponding compartment. Guillotine doors $(6 \times 5.2 \mathrm{~cm})$, patterned to match the outer compartments, separated the three compartments and were lowered on training days and raised on test days.

Conditioned place preference experimental design. Briefly, mice were handled for $1 \mathrm{~min}$ each day for $3 \mathrm{~d}$ before the start of the experiment (Days 1-3). The CPP procedure for all of the experiments was performed using an unbiased, counterbalanced protocol. Baseline preferences for each of the experiments were assessed by placing the animals in the center compartment of the place preference apparatus and allowing free access to all compartments for 15 min (pre-test; Day 4).

For the CREST mRNA and CREST protein expression experiment, animals were handled for $3 \mathrm{~d}$ and then given a pre-test the next day. The following day, animals were given saline or cocaine $(5,10$, or $20 \mathrm{mg} / \mathrm{kg}$ cocaine- $\mathrm{HCl}$ ) before a single $30 \mathrm{~min}$ exposure to one compartment and then were killed $30 \mathrm{~min}$ after the completion of the session.

For cocaine CPP behavioral experiments, all animals were treated identically through the pre-test. They are presented as separate groups during pre-test to show that both groups start off at similar pre-test preference scores (PSs). The following day, animals underwent intraNAc core infusions. The training stage began $2 \mathrm{~d}$ after surgeries. Conditioning was conducted over the subsequent $4 \mathrm{~d}$ with the guillotine doors closed, thus confining animals to one of the two outer compartments of the CPP apparatus for $30 \mathrm{~min}$ (Days $8-11$ ). An unbiased design was used so that half the animals were given cocaine before placement in the checkered compartment and half received cocaine immediately before placement in white compartment on training day 1 (CS+). The next day, treatment and compartment were reversed for each animal (training day 2 ); mice were injected with saline immediately before placement in the alternate compartment (CS-). Injections were alternated for subsequent conditioning sessions. For the $\mathrm{CPP}$ experiments, animals received a total of two 30 min pairings with cocaine in the CS + compartment and two 30 min pairings with saline in the CS- compartment. Forty-eight hours after the last conditioning session, preference (15 min; post-test; Day 13) was assessed in all animals as described above in a drug-free state.

In the synaptic physiology experiments (Fig. 4 and 5), animals underwent handling, a pre-test, intra-NAc infusion of Scrambled morpholino or anti-CREST morpholino, and then $2 \mathrm{~d}$ off for recovery. The following day, mice received saline or cocaine ( 5 or $10 \mathrm{mg} / \mathrm{kg}$ cocaine- $\mathrm{HCl}$ ) immediately before a single $30 \mathrm{~min}$ exposure to one compartment and then were killed $30 \mathrm{~min}$ after the completion of the session for recording.

\section{Slice preparation and recording}

Animals that received intra-NAc infusion of Scrambled morpholino or anti-CREST morpholino were used in these experiments. Parasagittal slices containing the NAc core were prepared as previously described (White et al., 2016). Briefly, following isoflurane anesthesia, mice were decapitated and the brain was quickly removed and submerged in icecold, oxygenated dissection medium containing the following (in $\mathrm{mM}$ ): $124 \mathrm{NaCl}, 3 \mathrm{KCl}, 1.25 \mathrm{KH}_{2} \mathrm{PO}_{4}, 5 \mathrm{MgSO}_{4}, 2.5 \mathrm{CaCl}_{2}, 26 \mathrm{NaHCO}_{3}$, and 10 
glucose. Parasagittal slices $(320 \mu \mathrm{m})$ were cut from the blocked brain using a FHC vibrating tissue slicer (model OTS-5000) before being transferred to an interface recording containing preheated artificial CSF of the following composition (in $\mathrm{mM}$ ): $124 \mathrm{NaCl}, 3 \mathrm{KCl}, 1.25 \mathrm{KH}_{2} \mathrm{PO}_{4}, 1.5$ $\mathrm{MgSO}_{4}, 2.5 \mathrm{CaCl}_{2}, 26 \mathrm{NaHCO}_{3}, 10$ glucose, and $10 \mu \mathrm{M}$ picrotoxin to reduce feedforward inhibition. Slices were continuously perfused with this solution at a rate of $1.75-2 \mathrm{ml} / \mathrm{min}$ while the surface of the slices were exposed to warm, humidified $95 \% \mathrm{O}_{2} / 5 \% \mathrm{CO}_{2}$ at $31 \pm 1^{\circ} \mathrm{C}$. Recordings began following at least $1.5 \mathrm{~h}$ of incubation.

Field EPSPs (fEPSPs) were recorded from NAc core by placing a single glass pipette (2-3 M $\Omega$ ) immediately adjacent to a bipolar stainless steel stimulating electrode ( $25 \mu \mathrm{m}$ diameter; FHC) positioned near the rostral end of the NAc core to activate afferent cortical fibers. Pulses were administered at $0.05 \mathrm{~Hz}$ using a current that elicited a $30-40 \%$ maximal response. Measurements of fEPSP slope (measured at $10-90 \%$ fall of the slope) were recorded during a minimum $20 \mathrm{~min}$ stable baseline period at which time LTP was induced by delivering $3-5$ trains (inter-train interval of $1 \mathrm{~min}$ ), each train containing five "theta" bursts, with each burst consisting of four pulses at $100 \mathrm{~Hz}$ and the bursts themselves separated by $200 \mathrm{~ms}$ [i.e., theta burst stimulation (TBS)]. The stimulation intensity was not increased during the delivery of TBS. Data were collected and digitized by NAC 2.0 Neurodata Acquisition System (Theta Burst) and stored on a disk. Data in figures on LTP were normalized to the last 10 min of baseline.

\section{Self-administration}

Apparatus and general behavioral methods. Behavioral experiments were performed in operant chambers (Med Associates) with two retractable levers above a grid floor with a house light. A cue light was positioned above each lever. One lever was paired with a cocaine infusion (take lever), whereas the other lever was designated as a seek lever. All experiments began with levers retracted and the house light extinguished. Animals were food restricted to maintain body weight and dosage during the course of the experiment.

Seeking-taking chain schedule experimental design: acquisition of cocaine self-administration under the take procedure. The seeking-taking chain schedule was adapted from Olmstead et al. (2000). The take procedure was modified from procedures described previously (Chen et al., 2013). Briefly, self-administration training began after 1 min with an insertion of the take lever and the illumination of the house light. One lever press on the take lever [fixed ratio (FR) 1] resulted in a single cocaine infusion $(0.89 \mathrm{mg} / \mathrm{kg}$ at a rate of $0.088 \mathrm{ml} / 5 \mathrm{~s})$, retraction of the take lever, illumination of a cue light above the take lever, and deactivation of the house light. Following a $30 \mathrm{~s}$ intertrial interval, another trial was initiated with an insertion of the take lever and illumination of the house light. Animals were given $5-7 \mathrm{~d}$ to earn 30 cocaine infusions $<4 \mathrm{~h}$ across 2 consecutive days on the take procedure. Once animals achieved this criterion (Day 1 and 2), the seek-take procedure was introduced (Days 3 and 4 ) as described below.

Self-administration experimental design: acquisition of cocaine selfadministration under the seek-take chain schedule. After each animal reached criteria described above, each trial in the seek-take chain schedule began with in insertion of the seek lever with the take lever retracted and illumination of the house light. One press on the seek lever (FR1) resulted in the retraction of the seek lever and the insertion of the take lever. One press on the take lever (FR1) resulted in a cocaine infusion, retraction of the take lever, illumination of the cue light, and deactivation of the house light. Following a $30 \mathrm{~s}$ intertrial interval, another trial was initiated with an insertion of the seek lever, deactivation of the cue light and the illumination of the house light. After $2 \mathrm{~d}$ of the FR1 seek-take schedule (Days 3 and 4), an increasing VI schedule of 2, 3, 5, and 10 s over 4 d (Day 5-VI 2, Day 6-VI 3, Day 7-VI 5, Day 8-VI 10, Day 9-VI 10, Day 10-VI 10) was introduced.

\section{Statistical analyses}

GraphPad Prism 7.02 was used for all statistical analysis. Data in the figure text are presented as means \pm SEM. Two-way ANOVAs followed by Bonferroni's post hoc tests were used to make specific comparisons when significant interactions and/or main group/test effects were ob- served. Group comparisons were analyzed by Student's $t$ tests or one-way ANOVAs when appropriate. For the self-administration experiment, $\beta$ is the regression coefficient (number of lever responses/time). For all analyses, an $\alpha$ value of 0.05 was required for significance.

\section{Results \\ CREST mRNA and CREST protein expression}

The goal of this study was to understand the role of CREST in cocaine action. We targeted the NAc core region (Fig. 1A), because this region plays a critical role in reward circuits. We examined immunoreactivity for CREST and how that overlaps with nuclei stained with DAPI and red fluorescent Nissl stain NeuroTrace staining. Our staining confirmed cell culture studies showing that CREST is a nuclear protein (Pradhan and Liu, 2004; Fig. $1 B)$. We next examined CREST mRNA and CREST protein expression during cocaine-CPP conditioning. The schematic of the CPP procedure is shown in Figure $1 C$ (fully described in Materials and Methods). NAc punches were taken from animals that received saline or cocaine $(5,10$, or $20 \mathrm{mg} / \mathrm{kg}$ cocaine- $\mathrm{HCl})$ immediately before a single $30 \mathrm{~min}$ exposure to one compartment and then were killed 30 min after the completion of the session. Gene expression was analyzed from tissue punches collected from the NAc. No changes in CREST mRNA were found after CPP conditioning with $5 \mathrm{mg} / \mathrm{kg}(n=7), 10 \mathrm{mg} / \mathrm{kg}(n=6)$, or $20 \mathrm{mg} / \mathrm{kg}(n=6)$ cocaine- $\mathrm{HCl}$ relative to conditioning with saline $\left(n=7 ; F_{(3,22)}=2.52 ; p=0.084\right.$, one-way ANOVA; Fig. $1 D)$. When CREST protein expression was analyzed from tissue punches collected from the NAc of the same animals, there were also no changes in CREST protein after CPP conditioning with 5 $\mathrm{mg} / \mathrm{kg}(n=7), 10 \mathrm{mg} / \mathrm{kg}(n=6)$, or $20 \mathrm{mg} / \mathrm{kg}(n=9)$ cocaine$\mathrm{HCl}$ relative to conditioning with saline $\left(n=10 ; F_{(3,28)}=1.392\right.$; $p=0.2657$, one-way ANOVA; Fig. $1 E$ ). These data demonstrate that acute cocaine exposure does not affect CREST mRNA or protein expression at the doses examined.

\section{siRNA targeting CREST in the nucleus accumbens core results in CREST protein knockdown and impairs cocaine CPP}

To use siRNA against CREST to examine the role of CREST in cocaine CPP, we first confirmed that the siRNA could keep CREST expression suppressed throughout the CPP experiment. Thus, we first performed a time course to evaluate the efficacy of the siRNA against CREST $2-6 \mathrm{~d}(n=3-4$ per hemisphere per day) following intra-NAc core siRNA infusion (Fig. $2 A$ ). Animals received siRNA targeting CREST in the NAc core in one hemisphere and nontargeting control siRNA in the other. Animals were subsequently killed and tissue samples of the NAc core were used for Western blot analysis to examine CREST knockdown. A two-way ANOVA was conducted. Because a treatment $\times$ day interaction was not reliable, we focused on the main effect result. A significant main treatment effect $\left(F_{(1,22)}=31.16 ; p<0.0001\right)$ was found, suggesting that the siRNA against CREST results in a significant reduction in CREST protein levels (Fig. 2A).

To investigate the hypothesis that CREST is necessary for the formation of cocaine CPP, mice were subjected to cocaine-CPP conditioning to examine the effect of NAc-specific CREST knockdown using siRNA on acquisition/consolidation/expression. The CPP procedure involves training animals to associate the rewarding properties of cocaine with a distinct cocainepaired environment versus a distinct vehicle-paired ( $0.9 \%$ saline) context. The schematic of the CPP procedure is shown in Figure $2 B$ (fully described in Materials and Methods) and was performed as described previously in our studies (Malvaez et al., 2011; Rogge et al., 2013; White et al., 2016; Alaghband et al., 
A
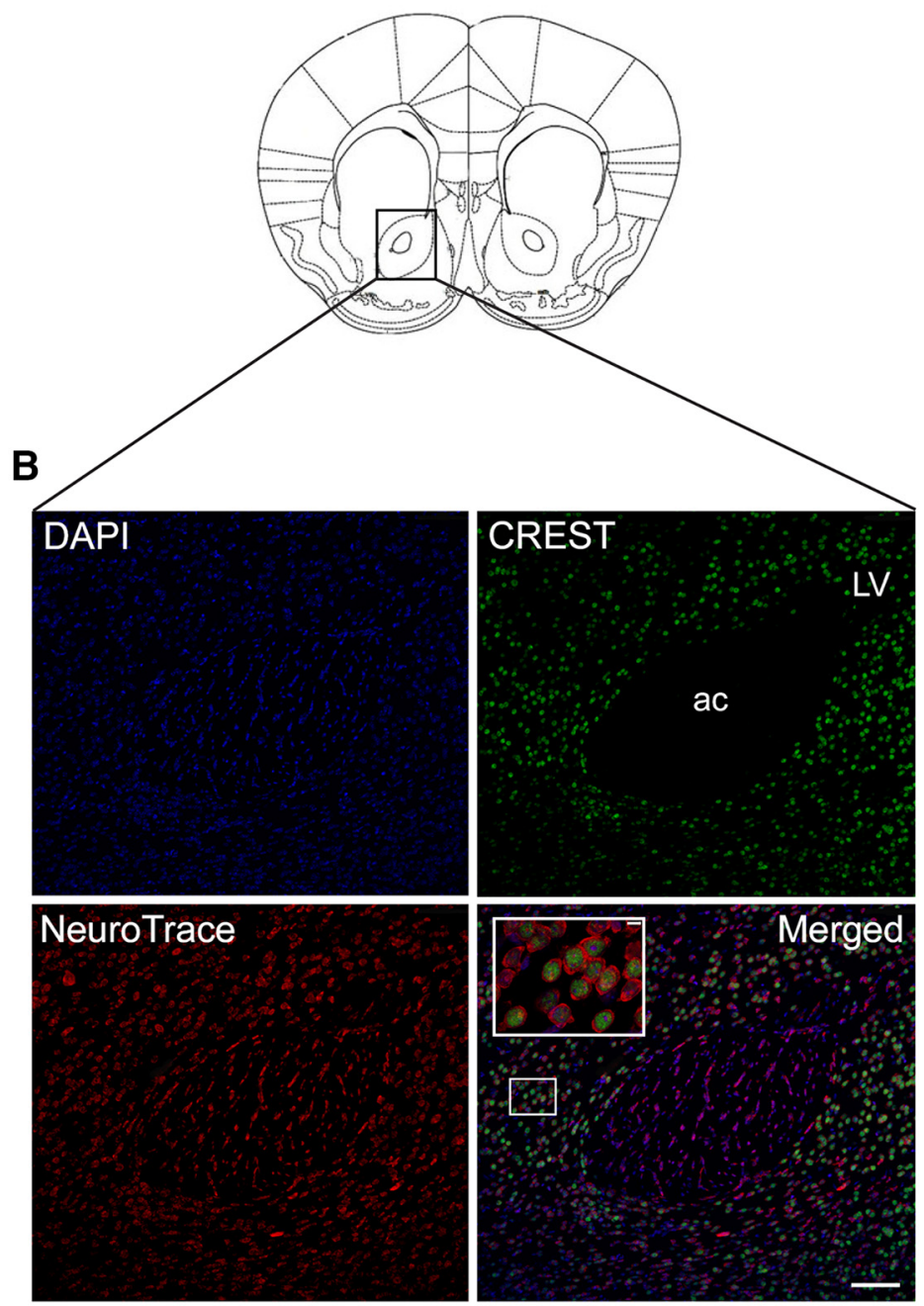

C
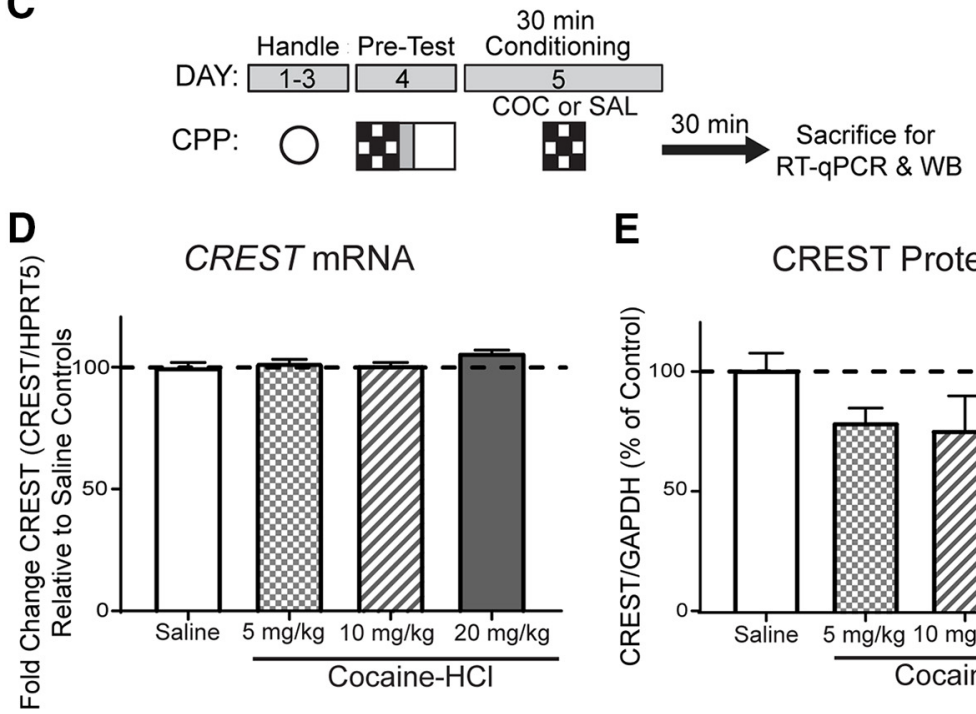

E

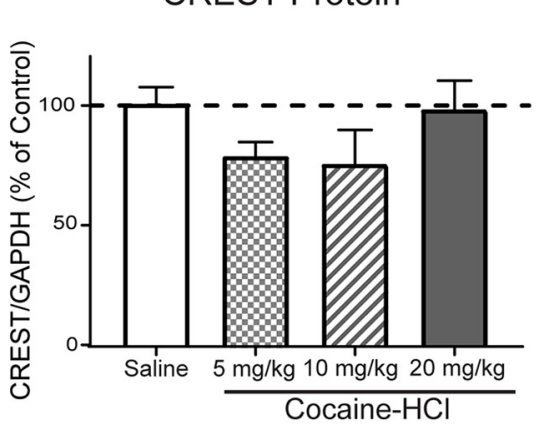

Figure 1. CREST expression. $\boldsymbol{A}$, Mouse atlas image illustrates the region of the NAc where the immunohistochemistry staining image was taken. $\boldsymbol{B}$, Immunoreactivity for CREST protein expression and its overlap with DAPI and NeuroTrace in NAc core is shown. CREST protein expression overlapping with DAPI and NeuroTrace staining. Scale bars: (in Merged) $7 \mu \mathrm{m}$; enlarged inset, $70 \mu \mathrm{m}$. $\boldsymbol{C}$, A schematic of the experimental design showing that data were collected from mice killed after either saline or $5,10,0 \mathrm{r} 20 \mathrm{mg} / \mathrm{kg}$ cocaine- $\mathrm{HCl}$ conditioning in a single cocaine-CPP trial (see Materials and Methods). D, Gene expression was analyzed from tissue punches collected from the NAc. No changes in CREST mRNA after CPP conditioning with 5, 10, or $20 \mathrm{mg} / \mathrm{kg}$ cocaine-HCl relative to
2017). The training dose of cocaine- $\mathrm{HCl}$ used for this experiment was $5 \mathrm{mg} / \mathrm{kg}$. A two-way repeated-measures ANOVA revealed a main effect of testing $\left(F_{(1,19)}=\right.$ 9.31; $p=0.0066)$ and no main treatment effect $\left(F_{(1,19)}=1.443 ; p=0.244\right)$. A trend toward a significant treatment group by test interaction $\left(F_{(1,19)}=3.77 ; p=0.067\right)$ was observed (Control siRNA, $n=9$; antiCREST siRNA, $n=12$; Fig. $2 C$ ).

When locomotion on test days was analyzed, we found that anti-CREST siRNA animals showed similar locomotion compared with nontargeting control siRNA animals (Fig. 2D). A two-way repeatedmeasures ANOVA revealed no effect of treatment group $\left(F_{(1,19)}=1.24 ; p=\right.$ $0.280)$ or interaction $\left(F_{(1,19)}=0.540 ; p=\right.$ $0.472)$. There was a trend toward an effect of testing $\left(F_{(1,19)}=3.627 ; p=0.0721\right)$, however, there was no difference in locomotion during pre- versus post-tests for either groups (Control: $t_{(19)}=1.746 ; p=$ 0.194; anti-CREST siRNA: $t_{(19)}=0.894$; $p=0.766$, Bonferroni post hoc; Control siRNA, $n=9$; anti-CREST siRNA, $n=12$; Fig. 2D). We next turned to a morpholino approach to knock down CREST because morpholinos are thought to be more stable, specific, and long-lasting than siRNAs (Moulton, 2017).

\section{Morpholino targeting CREST in the} nucleus accumbens core results in CREST protein knockdown and impairs cocaine CPP at a low dose, but not high dose, of cocaine

To further examine the role of CREST in cocaine CPP, we used a morpholino approach to block CREST expression in the NAc core. Before using morpholino against CREST to study the role of CREST in cocaine CPP, we first confirmed that morpholino could keep CREST expression down throughout the conditioning phase of cocaine CPP experiments. We conducted this experiment similarly to the experiment described in Figure $2 A$, but instead of examining CREST knockdown on all days, knockdown was exam-

conditioning with saline were observed. $E$, Protein expression from tissue punches collected from the NAc of the same animals was quantified using Western blot. No changes in CREST protein after CPP conditioning with 5,10 , or $20 \mathrm{mg} / \mathrm{kg}$ cocaine- $\mathrm{HCl}$ relative to conditioning with saline were found. For CREST mRNA expression experiment, $n=7$ for Saline, $n=$ 7 for $5 \mathrm{mg} / \mathrm{kg}$ cocaine- $\mathrm{HCl}, n=6$ for $10 \mathrm{mg} / \mathrm{kg}$ cocaine-HCl, and $n=6 \mathrm{for} 20 \mathrm{mg} / \mathrm{kg}$ cocaine-HCl. For CREST protein expression experiment, $n=10$ for Saline, $n=7$ for $5 \mathrm{mg} / \mathrm{kg}$ cocaine$\mathrm{HCl}, n=6$ for $10 \mathrm{mg} / \mathrm{kg}$ cocaine- $\mathrm{HCl}$, and $n=9$ for $20 \mathrm{mg} / \mathrm{kg}$ cocaine- $\mathrm{HCl}$ 


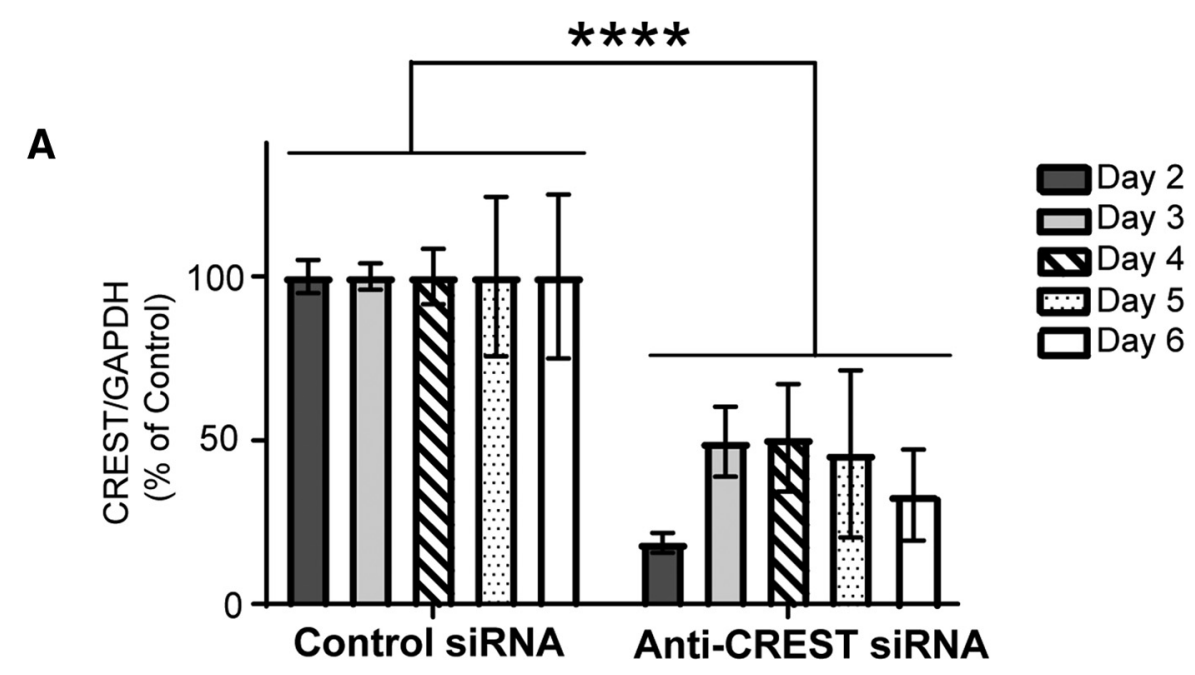

B

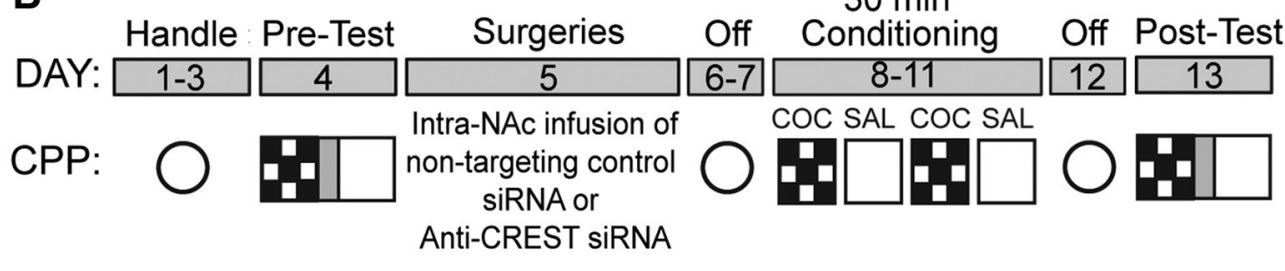

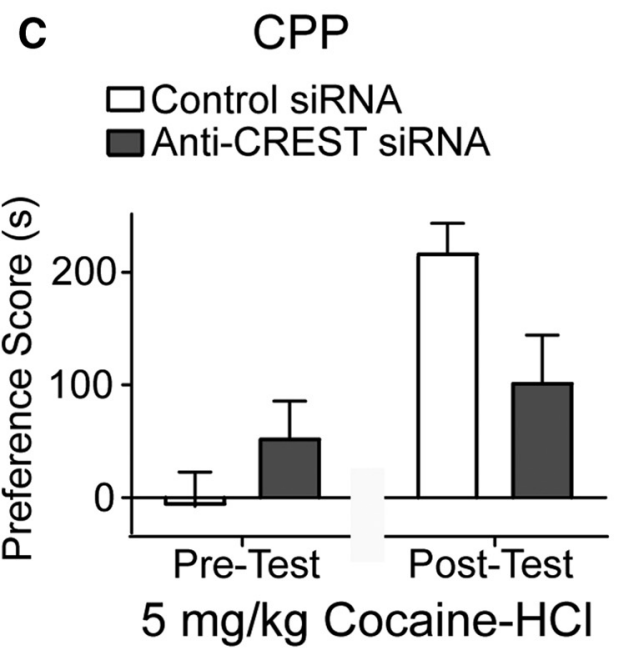

D Locomotion

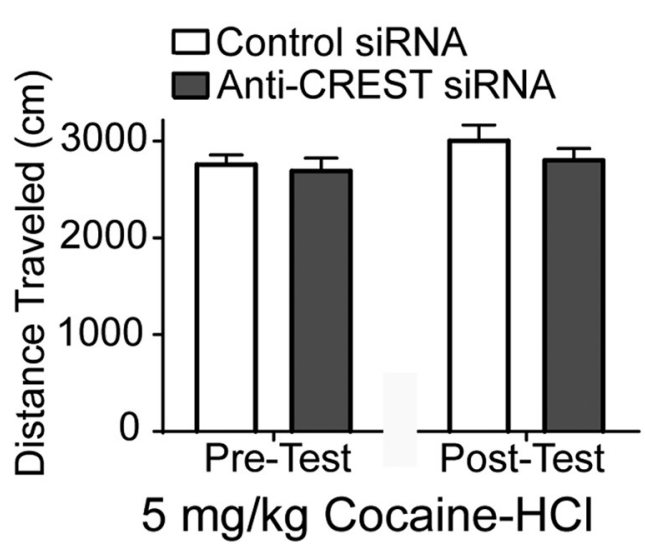

Figure 2. Anti-CREST siRNA in the NAc impairs cocaine CPP. A, Quantified Western blot data showing CREST protein levels following intra-NAc core siRNA infusion. siRNA anti-CREST in the NAC core results in a significant knockdown of CREST protein 2 $-6 \mathrm{~d}$ following infusion. $B$, Schematic of the cocaine CPP procedure. C, Cocaine CPP expression indicated by mean PS (CS +- CS - ) \pm SEM. At $5 \mathrm{mg} / \mathrm{kg}$ cocaine-HCl training dose, siRNA anti-CREST mice exhibited a trend toward significantly attenuated CPP PSs compared with Control siRNA. D, At $5 \mathrm{mg} / \mathrm{kg}$ cocaine-HCl training dose, anti-CREST siRNA animals showed similar locomotion compared with nontargeting siRNA. For time course experiment, $n=3-4$ per hemisphere per day. For cocaine CPP experiment, $n=9$ for Control siRNA and $n=12$ for anti-CREST siRNA. ${ }^{* * *} p<0.0001$.

ined on Days 2 and 6 ( $n=6$ per hemisphere per day). Two-way ANOVA revealed a significant main treatment effect $\left(F_{(1,20)}=\right.$ 7.151; $p=0.0146$; Fig. $3 A$ ), suggesting that the morpholino against CREST will reduce CREST protein levels throughout the conditioning phase of cocaine CPP experiments.

The CPP procedure used was the same as the one used for the siRNA experiment above (Fig. $2 B$ ). In the first experiment, animals were conditioned using $5 \mathrm{mg} / \mathrm{kg}$ cocaine- $\mathrm{HCl}$. In the remaining experiments of this manuscript, the Scrambled morpholino groups are labeled Control and the anti-CREST morpholino group as anti-CREST. As shown in Figure 3B, the anti-CREST group $(n=11)$ exhibited significantly attenuated CPP score compared with the Control group $(n=12)$. Using a two-way repeated-measures ANOVA, we found a significant treatment group by test interaction $\left(F_{(1,21)}=10.21 ; p=0.004\right)$, and a trend toward a main treatment group effect $\left(F_{(1,21)}=3.33\right.$; $p=0.082)$ as well as test effect $\left(F_{(1,21)}=3.86 ; p=0.063\right)$. Bonferroni post hoc analysis showed no initial preference for either context on the pre-test $\left(t_{(42)}=0.0097 ; p>0.99\right)$. However, there was a significant difference between the Control and the antiCREST group on the post-test $\left(t_{(42)}=3.17 ; p=0.0056\right)$, suggesting that knocking down CREST in the NAc core using morpholino significantly disrupts cocaine CPP at $5 \mathrm{mg} / \mathrm{kg}$ cocaine- $\mathrm{HCl}$ conditioning dose (Fig. $3 B$ ). When we analyzed locomotion on test day (Fig. $3 C$ ), we found that at the $5 \mathrm{mg} / \mathrm{kg}$ cocaine-HCl training dose, anti-CREST animals $(n=11)$ showed 

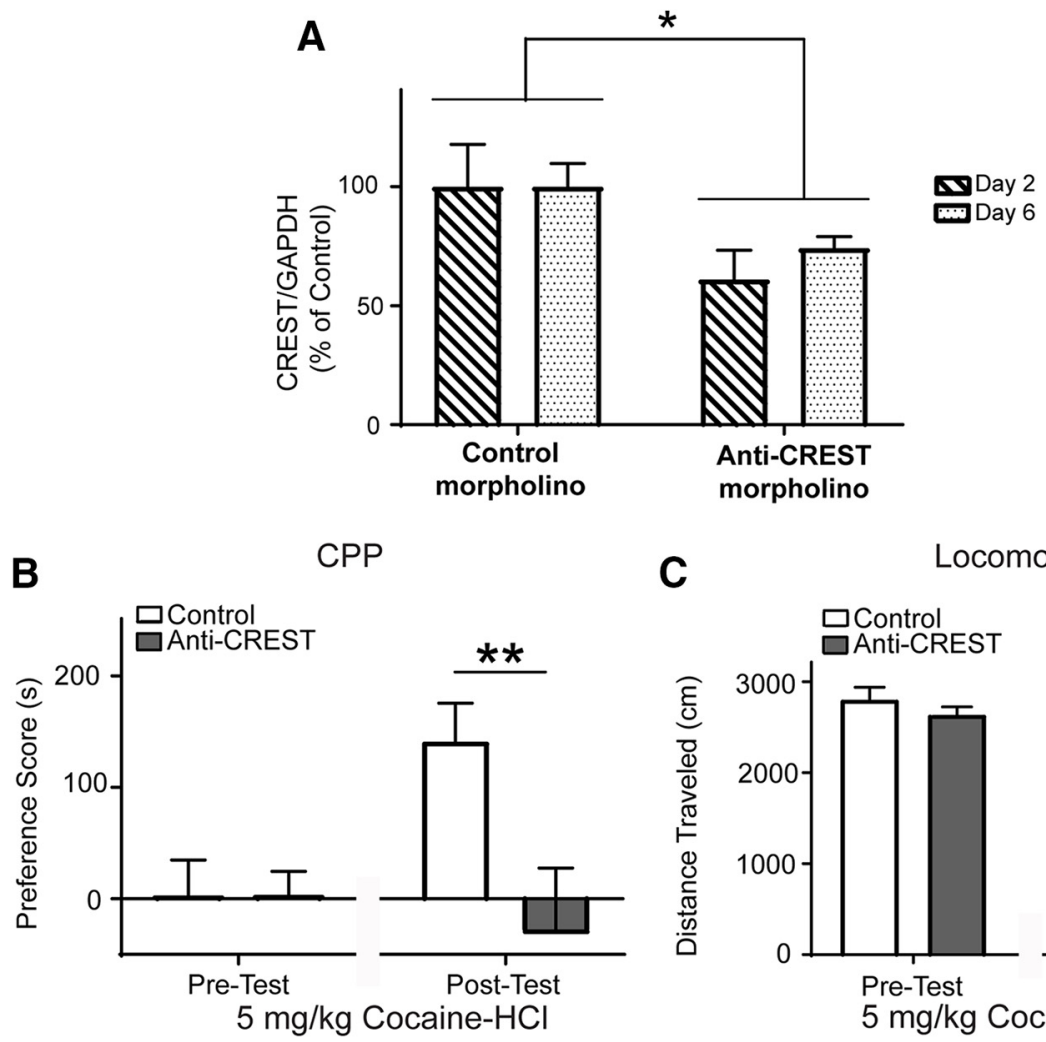

C

Locomotion

D

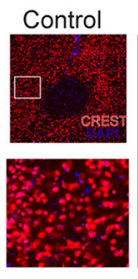

F
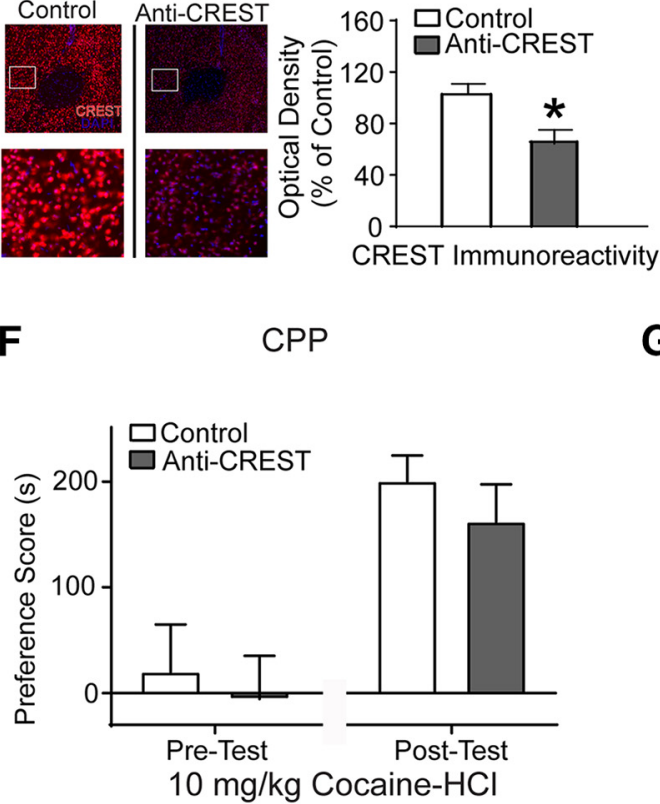

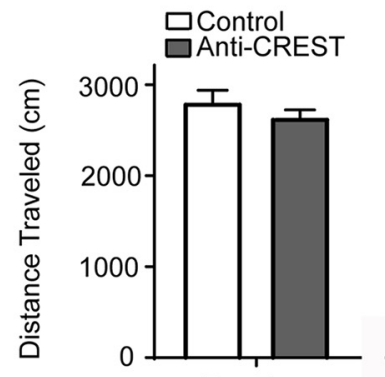

Pre-Test

E
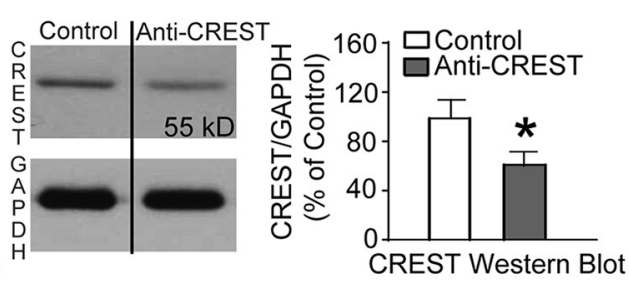

G

Locomotion

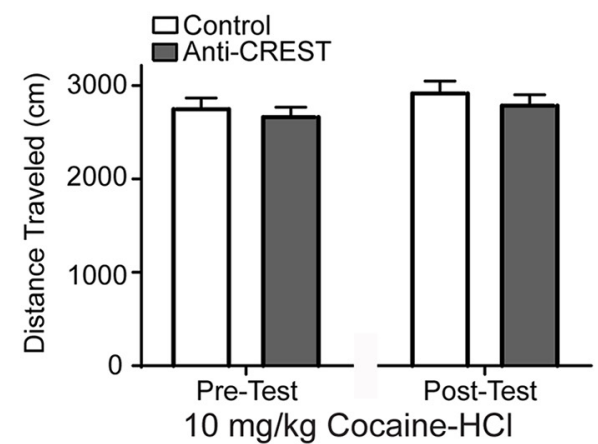

Figure 3. CREST knockdown in the NAc core using morpholino impairs cocaine CPP. A, Quantified Western blot data showing CREST protein levels following intra-NAc core morpholino infusion. Morpholino against CREST in the NAc core results in a significant knockdown of CREST protein 2 and 6 d postinfusion. $B$, Cocaine-CPP expression indicated by mean PS (CS +- CS - ) \pm SEM. At 5 $\mathrm{mg} / \mathrm{kg}$ cocaine-HCl training dose, anti-CREST morpholino mice (depicted as Anti-CREST in figure) show significantly attenuated PS compared with Scrambled morpholino control (depicted as Control in figure). C, At $5 \mathrm{mg} / \mathrm{kg}$ cocaine-HCl training dose, anti-CREST animals showed similar locomotion compared with Controls. D, Left, Representative image of CREST (red) expression in the $5 \mathrm{mg} / \mathrm{kg}$ cocaine-HCI CPP mice that had received intra-NAc infusion of Control or anti-CREST. Nuclei (blue) were counterstained with DAPI. Right, Mean intensity of CREST immunofluorescence from NAc core. There was a significant knock down in CREST in anti-CREST animals compared with Control. $\boldsymbol{E}$, Left, Representative Western blots showing reduced levels of CREST protein (55 kDa) with GAPDH as a loading/transfer control in the same animals. Right, Quantification of anti-CREST Western blot data. CREST protein was significantly knocked down in anti-CREST animals compared with Control. $F$, At $10 \mathrm{mg} / \mathrm{kg}$ cocaine-HCl training dose, no differences in PS were seen between groups. G, At $10 \mathrm{mg} / \mathrm{kg}$ cocaine-HCl training dose, anti-CREST animals showed similar locomotion compared with Controls. For time course experiment, $n=6$ per hemisphere per day. For $5 \mathrm{mg} / \mathrm{kg}$ cocaine CPP experiment, $n=12$ for Control and $n=11$ for anti-CREST. For $10 \mathrm{mg} / \mathrm{kg}$ cocaine CPP experiment, $n=$ 11 for Control and $n=10$ for anti-CREST. ${ }^{*} p<0.05,{ }^{* *} p<0.01$. 
similar locomotion compared with Controls $(n=12)$. A two-way repeated-measures ANOVA revealed no main effect of treatment group $\left(F_{(1,21)}=0.118 ; p=0.734\right)$, test $\left(F_{(1,21)}=0.00148 ; p=\right.$ $0.970)$, or interaction $\left(F_{(1,21)}=1.528 ; p=0.230\right.$; Fig. $\left.3 C\right)$.

One day after the post-test in the $5 \mathrm{mg} / \mathrm{kg}$ cocaine- $\mathrm{HCl}$ experiment (Fig. $3 B, C$ ), the animals were killed and tissue sections and samples of the NAc core was used for immunohistochemistry and Western blot analysis, respectively, to confirm knockdown. First, CREST knockdown was measured using immunohistochemistry and quantified (Fig. 3D) in the NAc-containing coronal slices of Control and anti-CREST mice with confirmed CREST knockdown from adjacent serial sections. Mean CREST optical density was significantly reduced in the NAc core of anti-CREST versus Control mice $\left(t_{(31)}=2.346 ; p=0.0255\right.$, unpaired $t$ test; Fig. $\left.3 D\right)$. Further, we also confirmed CREST knockdown by Western blot analysis on tissue samples from the NAc of Control and antiCREST animals. The anti-CREST samples showed significantly lower CREST protein levels compared with Controls $\left(t_{(21)}=\right.$ $2.209 ; p=0.0384$, unpaired $t$ test; Fig. $3 E$ ). Together, these results show that knockdown of CREST in the NAc core blocks the formation of cocaine-induced CPP.

We next examined dose-dependent effects by increasing the dose of cocaine to $10 \mathrm{mg} / \mathrm{kg}$ cocaine- $\mathrm{HCl}$ as the conditioning dose (Fig. $3 F$ ). A two-way repeated-measures ANOVA showed no interaction $\left(F_{(1,21)}=0.0606 ; p=0.808\right)$ or main effect of treatment group $\left(F_{(1,21)}=0.501 ; p=0.488\right)$. A significant main effect of test was observed $\left(F_{(1,21)}=43.28 ; p<0.0001\right.$; Control, $n=11$; anti-CREST, $n=10$; Fig. $3 F$ ). We examined the locomotor activity during the test day to assess whether there were any differences in the locomotor activating effects of cocaine (Fig. $3 G)$. A two-way repeated-measures ANOVA showed no main effect of testing $\left(F_{(1,19)}=2.711 ; p=0.116\right)$, treatment group $\left(F_{(1,19)}=1.098 ; p=0.308\right)$, or interaction $\left(F_{(1,19)}=0.0636 ; p=\right.$ 0.804; Control, $n=11$; anti-CREST, $n=10$; Fig. $3 G)$. CREST knockdown was confirmed using immunohistochemistry and Western blot analysis for every animal included in the CPP behavioral experiment shown in Figure 3, $F$ and $G$ (data not shown). Thus, blocking CREST in the NAc using the morpholino approach results in impaired cocaine $\mathrm{CPP}$ when a lower cocaine$\mathrm{HCl}(5 \mathrm{mg} / \mathrm{kg}$ cocaine- $\mathrm{HCl})$ training dose is used, but not when the dose is increased $(10 \mathrm{mg} / \mathrm{kg}$ cocaine- $\mathrm{HCl})$.

\section{Knocking down CREST in the nucleus accumbens core impairs LTP}

We next examined the effect of knocking down CREST in the NAc core on LTP during the consolidation phase of cocainecontext conditioning. We chose this time to understand how CREST knockdown affects the initial association of cocaine with a context, which may give rise to subsequent context preference. The schematic of the CPP, surgery procedures, and placement of stimulation and recording electrodes in an acute slice containing the NAc are shown in Figure $4 A$ (fully described in Materials and Methods). As shown in Figure $4 B$, the delivery of TBS to induce LTP in slices from animals that received the control morpholino into the NAc core and subsequently injected with saline showed an immediate increase in LTP that gradually decayed to a stable level of potentiation. This level of LTP in NAc core slices was found to be consistent with earlier reports in our laboratory (White et al., 2016). Two-way ANOVA analysis on the level of potentiation during the $50-60 \mathrm{~min}$ post-TBS period revealed a significant main group effect $\left(F_{(1,33)}=68.85 ; p<0.0001\right)$, main treatment effect $\left(F_{(1,33)}=8.369 ; p=0.0067\right)$, and a group by treatment interaction $\left(F_{(1,33)}=10.12 ; p=0.0032\right.$; Fig. $\left.4 C\right)$. The level of potentiation 60 min post-TBS was significantly reduced in slices prepared from animals that had received anti-CREST morpholino in the NAc followed by an intraperitoneal injection of saline (compared with slices from Control plus saline-injected animals; $t_{(33)}=3.765 ; p=0.0039$, Bonferroni post hoc; data normalized to the last 10 min of baseline), supporting the hypothesis that CREST is necessary for full-strength potentiation at glutamatergic synapses in the NAc (Fig. 4C). With regard to cocaine, TBS caused a pronounced sustainable increase in potentiation in slices from Control + cocaine-injected $(5 \mathrm{mg} / \mathrm{kg}$ cocaine- $\mathrm{HCl})$ animals relative to Control + saline-injected animals $\left(t_{(33)}=4.764 ; p=0.0002\right.$, Bonferroni post hoc; Control + saline, $n=12$; Control + cocaine, $n=10$; Fig. $4 C)$. In contrast, anti-CREST + cocaine-injected animals produced the same degree of LTP at the end of the recording period as shown in slices from anti-CREST + saline-injected animals $\left(t_{(33)}=0.1866 ; p>\right.$ 0.99 , Bonferroni post hoc; anti-CREST + saline, $n=8$; antiCREST + cocaine, $n=7)$. Further, anti-CREST + cocaineinjected animals showed significantly reduced potentiation compared with Control + cocaine-injected animals $\left(t_{(33)}=\right.$ 7.822; $p<0.0001$, Bonferroni post hoc). Together, these results show that $5 \mathrm{mg} / \mathrm{kg}$ cocaine- $\mathrm{HCl}$ cannot overcome the antiCREST morpholino-dependent impairment in NAc LTP.

Signs of any changes in baseline synaptic transmission due to the knockdown of CREST relative to controls were not evident in these animals. Input/output curves showed no significant changes between groups in slope of the EPSP across a range of intensities as analyzed using a two-way $\operatorname{ANOVA}\left(F_{(3,33)}=0.145\right.$; $p=0.9320$; Fig. $4 D$ ). Potential differences in transmitter release kinetics were also found to be negative because no noticeable difference between groups were measured in paired pulse facilitation $\left(F_{(3,34)}=2.06 ; p=0.1239\right.$, two-way ANOVA; Fig. $\left.4 E\right)$.

\section{Knocking down CREST in the nucleus accumbens core does not impair LTP in the presence of $10 \mathrm{mg} / \mathrm{kg}$ cocaine- $\mathrm{HCl}$} To understand why knocking down CREST using the morpholino approach failed to impair cocaine CPP at $10 \mathrm{mg} / \mathrm{kg}$ of cocaine- $\mathrm{HCl}$ training dose (Fig. $3 F$ ), we examined the effect of 10 $\mathrm{mg} / \mathrm{kg}$ of cocaine- $\mathrm{HCl}$ on LTP (Fig. 5A). Two-way ANOVA analysis on the level of potentiation during the 50-60 min post-TBS period revealed a significant main group (morpholino) effect $\left(F_{(1,21)}=35.88 ; p<0.0001\right)$, main injection (cocaine or saline) effect $\left(F_{(1,21)}=50.14 ; p<0.0001\right)$, and a group by injection interaction $\left(F_{(1,21)}=10.33 ; p=0.0042\right)$. Unlike the previous experiment (Fig. $4 B, C$ ), slices from Control mice injected with $10 \mathrm{mg} / \mathrm{kg}$ cocaine-HCl (Control + cocaine) had a similar level of stable potentiation $60 \mathrm{~min}$ post-TBS relative to Control mice that had received an injection of saline $\left(t_{(21)}=2.685 ; p=0.0831\right.$, Bonferroni post hoc; Control + saline: $n=6$, Control + cocaine: $n=6$; Fig. $5 B$ ). Additionally, as was the case with the previous experiment (Fig. $4 B, C$ ), the level of potentiation $60 \mathrm{~min}$ postTBS was significantly reduced in slices prepared from animals that had received anti-CREST in the NAc followed by an intraperitoneal injection of saline (compared with slices from Control + saline-injected animals; $t_{(21)}=6.39 ; p<0.0001$, Bonferroni post hoc; data in figures on LTP were normalized to the last $10 \mathrm{~min}$ of baseline; Control + saline, $n=6$; anti-CREST + saline, $n=6$; Fig. $5 B$ ). However, the higher dose of cocaine was able to overcome the anti-CREST-induced LTP deficit observed in the previous experiment (Fig. $4 B, C$ ). There was a significantly enhanced level of potentiation in animals infused with anti-CREST morpholino in the NAc core and injected with cocaine compared with anti-CREST animals injected with saline $\left(_{(21)}=7.418 ; p<\right.$ 
A
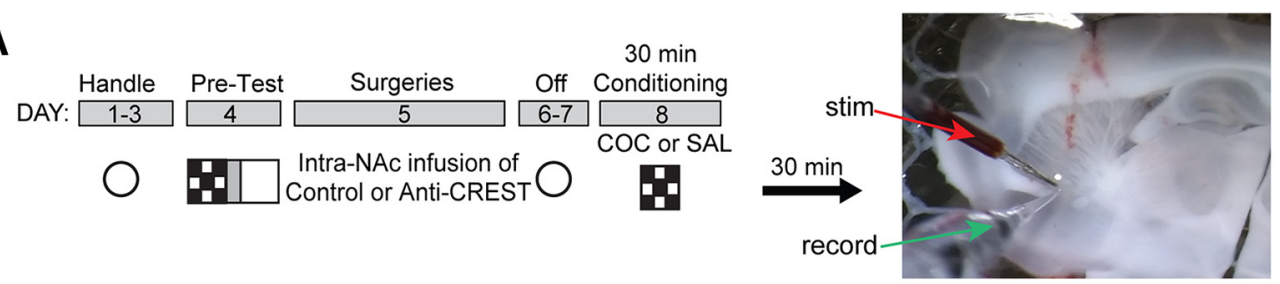

B

$5 \mathrm{mg} / \mathrm{kg}$ Cocaine- $\mathrm{HCl}$

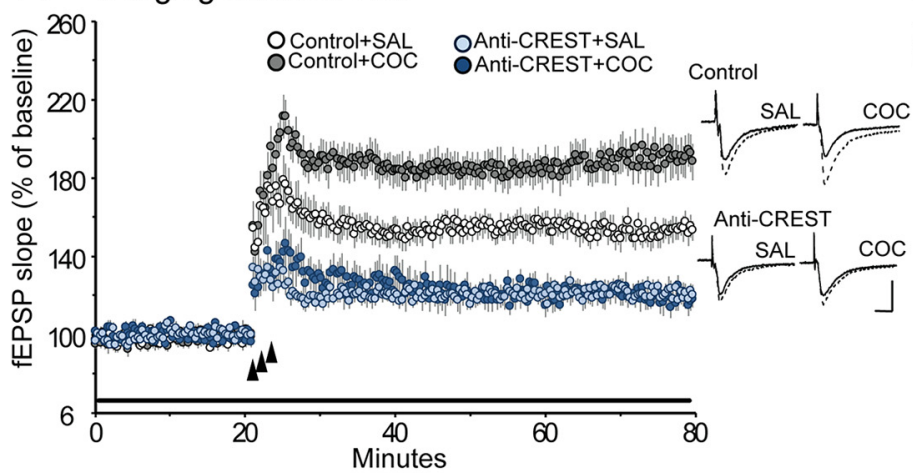

C

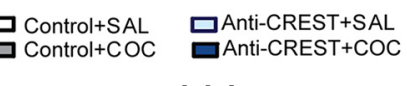

Control+COC $\square$ Anti-CREST+COC
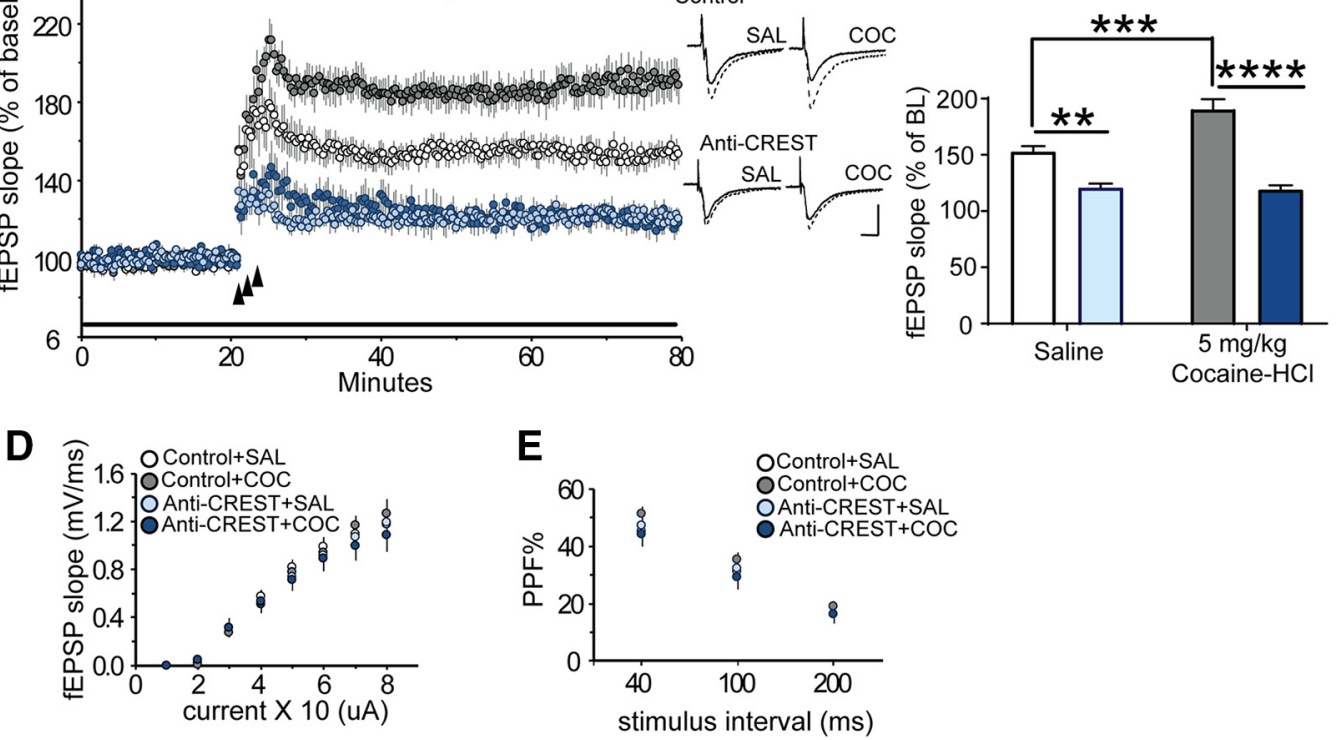

Figure 4. Anti-CREST morpholino blocks theta-burst-induced LTP in the NAc core. $A$, Left, Schematic describing the cocaine-CPP and image of an acute slice containing the NAc. Animals underwent handling, a pre-test, intra-NAc infusion surgeries, and then $2 \mathrm{~d}$ off. The next day, mice received either saline or $5 \mathrm{mg} / \mathrm{kg}$ cocaine-HCl immediately before a single 30 min exposure to one compartment. There was a $30 \mathrm{~min}$ lag period between the end of animal testing and sacrificing the animal for electrophysiology studies (horizontal black arrow). Right, Image illustrates the placement of the recording (green arrow) and stimulating (stim) electrode (red) in a NAc core slice. $\boldsymbol{B}$, Theta burst-induced LTP (3 small upward arrows) produced reliable stable potentiation in slices from control mice that received an infusion of control + injection of saline (Control + SAL; white circles, $n=12$ ). LTP was significantly enhanced in slices from Scrambled morpholino control (depicted as Control in figure) mice that received an intraperitoneal injection of $5 \mathrm{mg} / \mathrm{kg}$ cocaine-HCI (Control + COC; gray circles, $n=10$ ) compared with saline-injected mice. Infusions of anti-CREST morpholino (depicted as Anti-CREST in figure) into the NAc significantly impaired theta burst-induced LTP in this area in mice that received saline injections (light blue circles; $n=8$ ) relative to control mice; however, a $5 \mathrm{mg} / \mathrm{kg}$ dose of cocaine-HCl could not overcome anti-CREST-induced impairment in LTP (anti-CREST + COC; dark blue circles; $n=7$ ). There was a marked reduction in the level of potentiation $60 \mathrm{~min}$ post-TBS in these slices relative to control mice. Right, Representative traces collected during baseline (solid line) and 50 min post-TBS (dotted line) for each group. $C$, Summary graph representing average change in fEPSP slope as percentage of baseline (BL) for each group. Control animals that received $5 \mathrm{mg} / \mathrm{kg}$ cocaine- $\mathrm{HCl}$ showed facilitated potentiation compared with Control animals that received saline. The level of potentiation during $50-60$ min post-TBS period showed a significant reduction in anti-CREST + saline compared with Control + saline. anti-CREST + cocaine-HCl (5 mg/kg) also showed significantly reduced potentiation compared with Control + cocaine-HCl (5 mg/kg). D, Input (stimulation current)/output (slope of fEPSP) relationships were not detectably different between groups. $E$, Transmitter release kinetics, as assessed with paired pulse facilitation (PPF), were also comparable for the four groups of slices. Scale: $0.4 \mathrm{mV} / 5 \mathrm{~ms} .{ }^{* *} p<0.01,{ }^{* * *} p<0.001,{ }^{* * * *} p<0.0001$.

0.0001, Bonferroni post hoc; anti-CREST + saline, $n=6$; antiCREST + cocaine, $n=7$; Fig. $5 B$ ). The LTP measured in slices from mice infused with anti-CREST morpholino in the NAc core and injected with cocaine was indistinguishable from the level of potentiation achieved in slices from mice infused with control morpholino in the NAc and injected with cocaine $t_{(21)}=$ 2.001; $p=0.3512$, Bonferroni post hoc; Control + cocaine, $n=$ 6 ; anti-CREST + cocaine, $n=7$; Fig. $5 B$ ), which shows that a $10 \mathrm{mg} / \mathrm{kg}$ cocaine-HCl dose overcomes the anti-CREST morpholino-dependent impairment in NAc LTP, unlike the lower dose of $5 \mathrm{mg} / \mathrm{kg}$. We also evaluated whether the higher dose of cocaine altered baseline synaptic transmission. As shown in Figure 5, $C$ and $D$, the input/output curves $\left(F_{(3,21)}=\right.$ 0.1933; $p=0.8998$, two-way ANOVA) and paired-pulse facilitation $\left(F_{(3,21)}=1.503 ; p=0.2427\right)$ did not show significant changes between groups.
CREST knockdown in the nucleus accumbens core slows the acquisition of a chain schedule in which rats perform a sequential instrumental response to receive cocaine

In the next experiment, we tested whether CREST in the nucleus accumbens core also plays a role in self-administration using rats. The Control and anti-CREST groups' total lever presses were similar throughout the FR1 take, FR1 seek-take, VI2-10 schedule (Fig. 6A). However, the introduction of the seek-take chain schedule significantly increased the time to complete the session for the anti-CREST group compared with the Control group (Day 3 anti-CREST vs Control: $t_{(8)}=4.178 ; p=0.003$; Day 4 anti-CREST vs Control: $t_{(8)}=3.190 ; p=0.01$; Figure $6 B$ ). There were no differences in cumulative responses over time during the final take session $\left(\beta_{\mathrm{CONTROL}}=13.03 ; \beta_{\mathrm{CREST}}=12.98 ; t=0.206\right.$; $p=0.84$, unpaired $t$ test; Fig. $6 C$ ), but there were reliable differences during the first seek-take day $\left(\beta_{\mathrm{CONTROL}}=11.67 ; \beta_{\mathrm{CREST}}=\right.$ 
A $10 \mathrm{mg} / \mathrm{kg}$ Cocaine- $\mathrm{HCl}$
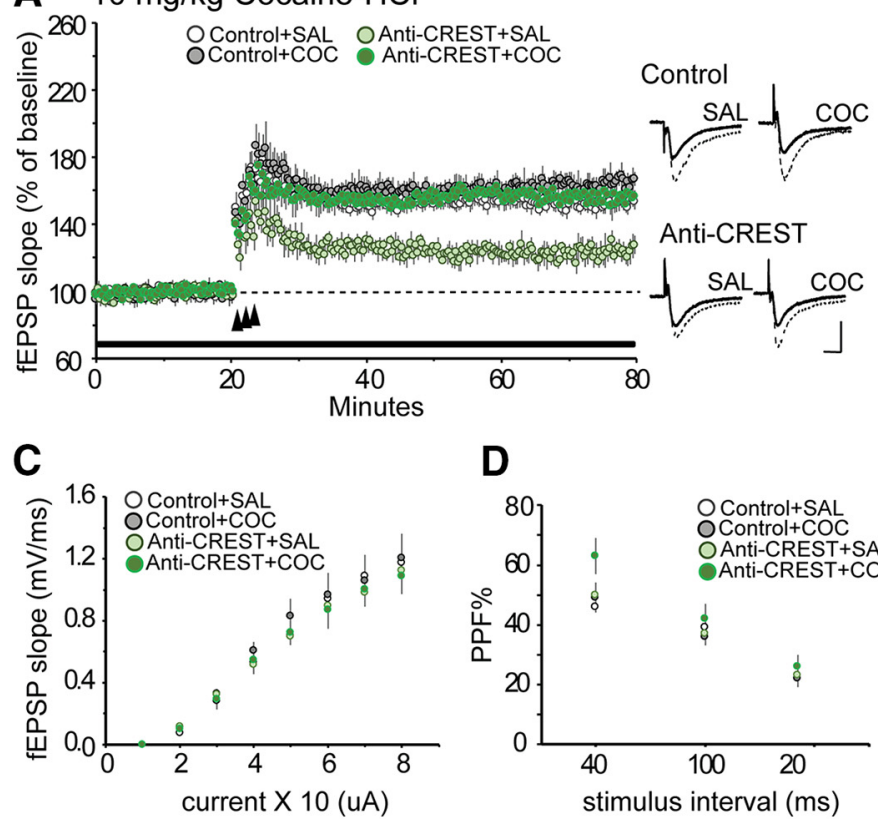

D

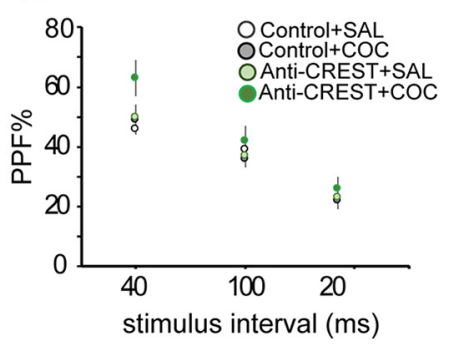

B

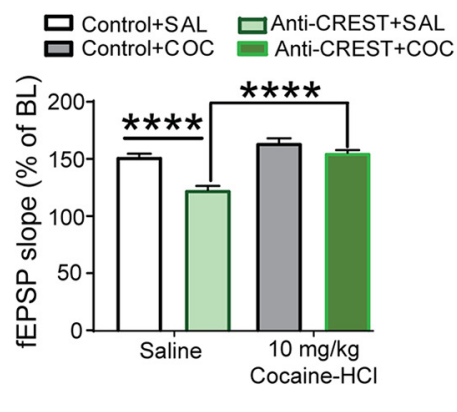

Figure 5. Higher dose of cocaine overcomes anti-CREST-induced LTP impairment. $A$, Left, Conditions were the same as described in Figure $4 A$ with the exception that animals received $10 \mathrm{mg} / \mathrm{kg}$ cocaine-HCl before the single 30 min exposure to one compartment. In figure, anti-CREST morpholino mice is depicted as Anti-CREST and Scrambled morpholino control is depicted as Control. Slices from control animals injected with the higher dose of cocaine (Control + COC; gray circles; $n=6$ ) produced LTP in the NAc that was indistinguishable from the LTP measured in slices from control animals injected with saline (Control +SAL; white circles; $n=6$ ). The $10 \mathrm{mg} / \mathrm{kg}$ dose of cocaine was effective in rescuing anti-CREST-induced LTP (anti-CREST +COC; dark green circles; $n=7$ ), which was found to produce a similar level of potentiation as in slices from control mice injected with saline. NAc slices from mice infused with anti-CREST and injected with saline (anti-CREST + SAL; light green circles; $n=6$ ) produced the predicted deficit in LTP relative to control mice. Right, Representative traces collected during baseline (solid line) and 50 min post-TBS (dotted line) for each group. $\boldsymbol{B}$, The average level of potentiation during $50-60 \mathrm{~min}$ post-TBS period showed a significant enhancement in potentiation in anti-CREST + cocaine (10 mg/kg cocaine-HCI) animals versus anti-CREST + saline. There was a significant reduction in anti-CREST + saline compared with Control + saline. C, The $10 \mathrm{mg} / \mathrm{kg}$ dose did not affect the input/out curves measured before delivery of TBS. D, Paired pulse facilitation (PPF) curves were equivalent in slices from each group tested. Scale: $0.4 \mathrm{mV} / 5 \mathrm{~ms}$. ${ }^{* * * *} p<0.0001$.

7.14; $t=69.81 ; p<0.0001$, unpaired $t$ test; Control, $n=5$; anti-CREST, $n=5$; Fig. $6 D$ ). Similar to the results of the high dose of cocaine on CPP and LTP, increasing the demands for receiving a cocaine reward by increasing the variable interval schedule on the seek lever from VI 2 to VI $10 \mathrm{~s}$ attenuated the deficit of the anti-CREST group (Days 5-10, $F=2.032 ; p=$ 0.213 , two-way repeated-measures ANOVA). At the end of the experiment, CREST knockdown was measured using Western blot analysis (Fig. 6E) and quantified (Fig. 6F). The anti-CREST samples showed significantly reduced CREST protein levels compared with Control samples $\left(t_{(8)}=2.256 ; p=0.0355\right.$, unpaired $t$ test; Control, $n=5$; anti-CREST, $n=5$; Fig. $6 F$ ). These results suggest that morpholino against CREST in the NAc had no effect on first-order responding for cocaine, but slowed the acquisition of a chain schedule in which rats had to perform a sequence of instrumental responses to receive cocaine.

\section{Discussion}

In this study, we examined the role of CREST in cocaine CPP and cocaine-seeking behavior as well as synaptic plasticity in the NAc. Mouse cocaine-induced CPP experiments demonstrated that CREST is required for the formation of cocaine-induced CPP and a rat self-administration experiment demonstrated that CREST is also important for the acquisition/consolidation of the seek-take chain schedule. We also found that CREST is required for thetaburst LTP in the NAc, a form of synaptic plasticity. Together these results suggest that CREST is an important downstream target of cocaine action.

In the CPP and LTP experiments, we found cocaine dosedependent effects. A low dose of cocaine- $\mathrm{HCl}$ ( $5 \mathrm{mg} / \mathrm{kg}$ ) used for conditioning led to impaired cocaine-induced CPP. NAc LTP was also impaired by knockdown of CREST regardless of whether animals received saline or cocaine $(5 \mathrm{mg} / \mathrm{kg})$ during the single conditioning trial. For the LTP experiment, we chose one pairing of context and cocaine- $\mathrm{HCl}$ because this is sufficient to observe significant preference in a $24 \mathrm{~h}$ test (data not shown) and it is a time point when initial molecular mechanisms are in play that may be involved in the consolidation phase between a context and cocaine$\mathrm{HCl}$ (Rogge et al., 2013). At the lower dose of cocaine- $\mathrm{HCl}$ (5 mg/ $\mathrm{kg}$ ), reducing CREST expression using the morpholino approach resulted in a significant impairment in LTP.

However, at a higher dose of cocaine- $\mathrm{HCl}(10 \mathrm{mg} / \mathrm{kg})$ we observed no behavioral impairments in cocaine-induced CPP in animals receiving the anti-CREST morpholino in the NAc. Similarly, there were no impairments in NAc LTP in slices from animals receiving anti-CREST morpholino and $10 \mathrm{mg} / \mathrm{kg}$ cocaine. Thus, the knockdown of CREST blocks cocaine action at 5 $\mathrm{mg} / \mathrm{kg}$, but not at $10 \mathrm{mg} / \mathrm{kg}$. The higher dose is likely sufficient to induce more powerful signaling perhaps by more persistent activation of signaling pathways or induction of additional molecular mechanisms, or there may be compensation by the interaction partners of CREST, such as CBP- or BRG1-dependent mechanisms. Understanding this difference could provide important insight into the mechanistic differences between lower and higher doses of cocaine. In any case, the similar effects observed behaviorally and at the level of synaptic plasticity in the NAc suggest that the approach of examining LTP after the first conditioning trial may be fundamentally relevant to the behavioral phenotype observed in the CPP task. 


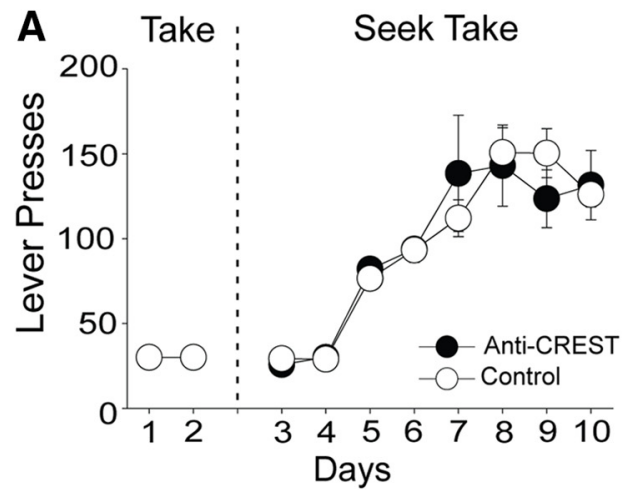

C

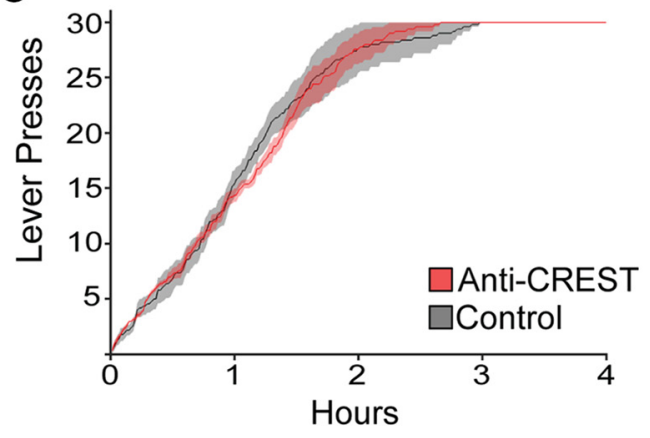

$\mathbf{E}$
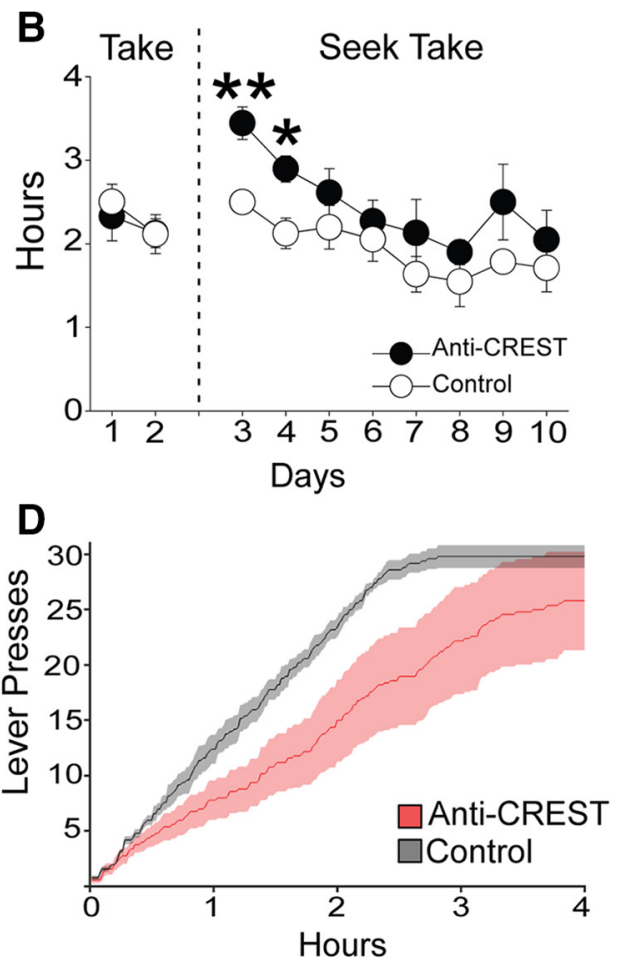

$\mathbf{F}$

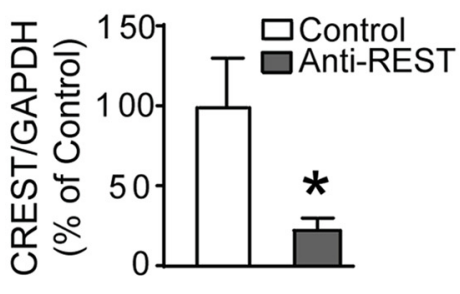

Figure 6. CREST knockdown in the NAc core initially impairs the acquisition of a chain schedule in a rat self-administration model. $\boldsymbol{A}, \boldsymbol{B}$, Lever pressing behavior $(\boldsymbol{A})$ and time to completion ( $\boldsymbol{B})$ during the final two sessions of take responding (Days 1 and 2), and the eight sessions of seek-take responding with increasing VI requirements on the seek lever (Days 3-10; see Materials and Methods). Anti-CREST and Control animals total lever presses were similar ( $\boldsymbol{A})$, but introduction of the seek-take chain schedule significantly increased the time to complete session with the introduction of the seek-take chain schedule (Days 3 and 4), which was attenuated with the increasing VI schedule (B). C, D, Cumulative lever press plots for Scrambled morpholino control (Control) and anti-CREST morpholino (Anti-CREST) animals. C, Control and anti-CREST groups displayed similar lever pressing frequency during the final day of the FR1 take procedure (Day 2; shaded region = $\mathrm{SE} ; p>0.1)$. D, An introduction of a seek-take chain schedule of reinforcement significantly reduced lever pressing frequency for the anti-CREST but not the Control group during the first day of seek-take training (Day 3). $\boldsymbol{E}$, Representative Western blot comparing the expression of CREST protein (55 kDa) in Control and anti-CREST rats. $\boldsymbol{F}$, CREST Protein was significantly knocked down in the anti-CREST group compared with Control. $n=5$ for Control and $n=5$ for anti-CREST. ${ }^{*} p<0.05,{ }^{* *} p<0.01$.

Indeed, we have found similar observations in a previous study examining the role of BAF53b in cocaine-induced CPP and NAc LTP (White et al., 2016). BAF53b is a neuron-specific subunit of the nBAF nucleosome-remodeling complex and interacts with BRG1. In that study, we found that Baf53b+/- heterozygous knock-out mice exhibited impaired CPP at $5 \mathrm{mg} / \mathrm{kg}$ of cocaine- $\mathrm{HCl}$, but normal CPP at $10 \mathrm{mg} / \mathrm{kg}$. In contrast, CaMKIIBaf53b $\Delta$ HD transgenic mice exhibited impaired CPP at both 5 and $10 \mathrm{mg} / \mathrm{kg}$. CaMKII-Baf53b $\Delta \mathrm{HD}$ transgenic mice express a deletion mutant of BAF53b missing the hydrophobic domain of BAF53b, which is thought to generate a dominant-negative of the protein. The difference between the Baf $53 \mathrm{~b}+/-$ heterozygous knock-out mice and the CaMKII-Baf53b $\Delta$ HD transgenic mice is likely because the Baf53b $\Delta \mathrm{HD}$ deletion mutant disrupts nBAF activity (as a dominant-negative), whereas the nBAF complex is still able to be formed and be functional to some degree in the Baf53b+/- heterozygous knock-out mice. When examining NAc LTP in slices from those animals, slices from CaMKII-
Baf53b $\Delta \mathrm{HD}$ transgenic mice had significantly lower LTP than slices from Baf53b+/- heterozygous knock-out mice. LTP in slices from Baf53b + / - heterozygous knock-out mice was modestly impaired compared with wild-type slices. Together, the results suggested that the level of NAc LTP correlated with the ability to form a cocaine-induced CPP. In that previous study, we also found that theta-burst LTP in the NAc is BDNF-dependent (White et al., 2016). Delivering BDNF to the NAc rescued the CPP impairment, as well as the LTP impairment in CaMKIIBaf53b $\Delta$ HD transgenic mice (White et al., 2016). Results from the White et al. (2016) study and the results from the current study suggest that long-term synaptic changes in the NAc may be a key cellular mechanism involved in CPP behavior, and it is possible that the level of NAc LTP may correlate with the ability to form cocaine-induced CPP.

It is important to point out that in the CREST expression experiment, CREST mRNA and CREST protein measurements were obtained after acute, not chronic, cocaine administration 
at various doses $(5,10$, or $20 \mathrm{mg} / \mathrm{kg}$ cocaine- $\mathrm{HCl})$. We examined CREST expression at this time to match the LTP experiment timing. However, it is quite possible that chronic cocaine may affect CREST expression, which would then have a significant impact on downstream regulation of CREST target genes and potentially genes regulated in a coordinate manner by CREST/CBP/BRG1.

To examine the role of CREST beyond cocaine-induced CPP, we also examined aspects of cocaine self-administration, which supported and extended the findings from the CPP experiments. In the self-administration experiment, CREST knockdown in the NAc core had no effect on instrumental responding for cocaine itself on a first-order schedule, suggesting that motivation to respond for cocaine was unaffected by the knockdown, but it did significantly attenuate responding during the acquisition of a second-order chain schedule, in which responding has a temporally discontiguous association with cocaine. Second-order conditioning has been shown to be NAc-dependent (Setlow et al., 2002; McDannald et al., 2013), thus it is not surprising that as the self-administration changed from a first-order to a second-order schedule, animals with reduced CREST levels in the NAc showed an attenuation in learning. Increasing the VI schedule demands attenuated the initial deficit in the anti-CREST morpholinotreated animals. Together, these results are consistent with CREST in the NAc being critical for initial learning involving a second-order schedule of reinforcement and they mirror the dose-dependent effects of cocaine on CPP and LTP, where the effects were pronounced with lower doses of cocaine. There is evidence to suggest that increased training on instrumental tasks progresses from goal directed to habitual behavior reflecting a transition from one cortical-striatal system to another (Everitt, 2014). Consequently, while CREST knockdown in the NAc may impair the learning of the seek-take schedule, extended instrumental second-order training may have engaged alternate cortico-striate circuitry to attenuate the deficits between groups (Di Ciano and Everitt, 2005).

To date, CREST has been mainly characterized in cell culture studies. CREST was initially identified while screening for calcium-induced transactivators (Aizawa et al., 2004). CREST is activated by calcium influx in response to neuronal depolarization and CREST knock-out mice are viable, but only $20 \%$ survive to adulthood and their cultured neurons display defects in calcium-dependent dendritic growth (Aizawa et al., 2004; Qiu and Ghosh, 2008). Recently, two human mutations have been identified in CREST that are thought to give rise to amyotrophic lateral sclerosis (Chesi et al., 2013). One of the mutations results in a deletion of 9 aa of CREST, which destroys the CBP binding domain and generates a mutant form of CREST that is unable to regulate transcription (Aizawa et al., 2004; Chesi et al., 2013). The other mutation is a missense mutation, which blocks depolarization-induced dendritic outgrowth (Chesi et al., 2013). Further, Mathies et al. (2017) recently found that allelic variation in SS18L1 (which encodes CREST) was associated with alcohol dependence in humans. Together, these studies demonstrate the need to understand the role of CREST in controlling gene expression involved in synaptic structure and function, spine morphology, and cocaine-induced alterations to these cellular structures and their function.

In summary, this study examined the role of CREST in vivo, specifically in cocaine action and synaptic plasticity. At $5 \mathrm{mg} / \mathrm{kg}$ cocaine- $\mathrm{HCl}$, blocking CREST in the NAc core using the morpholino approach resulted in impaired cocaine CPP as well as LTP in the NAc. But, the higher dose of cocaine $(10 \mathrm{mg} / \mathrm{kg}$ cocaine- $\mathrm{HCl}$ ) was able to overcome anti-CREST morpholinodependent impairment in the NAc in both CPP as well as LTP. Along the same lines, CREST knockdown in the NAc core significantly impaired responding on a second-order chain schedule involving weaker cocaine association, but had no effect on instrumental responding for cocaine itself on a first-order schedule in self-administration. Together, our findings support the overall idea that CREST may be playing a key function of coordinating histone acetylation and nucleosome remodeling during cocaine-dependent calcium signaling for the regulation of gene expression.

\section{References}

Aizawa H, Hu SC, Bobb K, Balakrishnan K, Ince G, Gurevich I, Cowan M, Ghosh A (2004) Dendrite development regulated by CREST, a calciumregulated transcriptional activator. Science 303:197-202. CrossRef Medline

Alaghband Y, Kwapis JL, López AJ, White AO, Aimiuwu OV, Al-Kachak A, Bodinayake KK, Oparaugo NC, Dang R, Astarabadi M, Matheos DP, Wood MA (2017) Distinct roles for the deacetylase domain of HDAC3 in the hippocampus and medial prefrontal cortex in the formation and extinction of memory. Neurobiol Learn Mem 145:94-104. CrossRef Medline

Chen BT, Yau HJ, Hatch C, Kusumoto-Yoshida I, Cho SL, Hopf FW, Bonci A (2013) Rescuing cocaine-induced prefrontal cortex hypoactivity prevents compulsive cocaine seeking. Nature 496:359-362. CrossRef Medline

Chesi A, Staahl BT, Jovičić A, Couthouis J, Fasolino M, Raphael AR, Yamazaki T, Elias L, Polak M, Kelly C, Williams KL, Fifita JA, Maragakis NJ, Nicholson GA, King OD, Reed R, Crabtree GR, Blair IP, Glass JD, Gitler AD (2013) Exome sequencing to identify de novo mutations in sporadic ALS trios. Nat Neurosci 16:851-855. CrossRef Medline

Di Ciano P, Everitt BJ (2005) Neuropsychopharmacology of drug seeking: insights from studies with second-order schedules of drug reinforcement. Eur J Pharmacol 526:186-198. CrossRef Medline

Everitt BJ (2014) Neural and psychological mechanisms underlying compulsive drug seeking habits and drug memories: indications for novel treatments of addiction. Eur J Neurosci 40:2163-2182. CrossRef Medline

Hargreaves DC, Crabtree GR (2011) ATP-dependent chromatin remodeling: genetics, genomics and mechanisms. Cell Res 21:396-420. CrossRef Medline

Hyman SE, Malenka RC, Nestler EJ (2006) Neural mechanisms of addiction: the role of reward-related learning and memory. Annu Rev Neurosci 29:565-598. CrossRef Medline

Jenuwein T, Allis CD (2001) Translating the histone code. Science 293: 1074-1080. CrossRef Medline

Kalivas PW, Volkow ND (2005) The neural basis of addiction: a pathology of motivation and choice. Am J Psychiatry 162:1403-1413. CrossRef Medline

Kouzarides T (2007) Chromatin modifications and their function. Cell 128: 693-705. CrossRef Medline

Kumar A, Choi KH, Renthal W, Tsankova NM, Theobald DE, Truong HT, Russo SJ, Laplant Q, Sasaki TS, Whistler KN, Neve RL, Self DW, Nestler EJ (2005) Chromatin remodeling is a key mechanism underlying cocaineinduced plasticity in striatum. Neuron 48:303-314. CrossRef Medline

Kwapis JL, Alaghband Y, López AJ, White AO, Campbell RR, Dang RT, Rhee D, Tran AV, Carl AE, Matheos DP, Wood MA (2017) Context and auditory fear are differentially regulated by HDAC3 activity in the lateral and basal subnuclei of the amygdala. Neuropsychopharmacology 42:12841294. CrossRef Medline

López AJ, Kramár E, Matheos DP, White AO, Kwapis J, Vogel-Ciernia A, Sakata K, Espinoza M, Wood MA (2016) Promoter-specific effects of DREADD modulation on hippocampal synaptic plasticity and memory formation. J Neurosci 36:3588-3599. CrossRef Medline

Levine AA, Guan Z, Barco A, Xu S, Kandel ER, Schwartz JH (2005) CREBbinding protein controls response to cocaine by acetylating histones at the fosB promoter in the mouse striatum. Proc Natl Acad Sci U S A 102: 19186-19191. CrossRef Medline

Macks C, Lee JS (2016) Non-viral vector mediated RNA interference technology for central nervous system injury. DNA RNA Nanotechnol 3:1. CrossRef 
Malvaez M, Mhillaj E, Matheos DP, Palmery M, Wood MA (2011) CBP in the nucleus accumbens regulates cocaine-induced histone acetylation and is critical for cocaine-associated behaviors. J Neurosci 31:16941-16948. CrossRef Medline

Mathies LD, Aliev F, Davies AG, Dick DM, Bettinger JC (2017) Variation in SWI/SNF chromatin remodeling complex proteins is associated with alcohol dependence and antisocial behavior in human populations. Alcohol Clin Exp Res 41:2033-2040. CrossRef Medline

McDannald MA, Setlow B, Holland PC (2013) Effects of ventral striatal lesions on first- and second-order appetitive conditioning. Eur J Neurosci 38:2589-2599. CrossRef Medline

Moulton JD (2007) Using morpholinos to control gene expression. Curr Protoc Nucleic Acid Chem 27:4.30.1-4.30.24. CrossRef Medline

Moulton JD (2017) Making a morpholino experiment work: controls, favoring specificity, improving efficacy, storage, and dose. Methods Mol Biol 1565:17-29. CrossRef Medline

Olmstead MC, Parkinson JA, Miles FJ, Everitt BJ, Dickinson A (2000) Cocaine-seeking by rats: regulation, reinforcement and activation. Psychopharmacology (Berl) 152:123-131. CrossRef Medline

Parrish JZ, Kim MD, Jan LY, Jan YN (2006) Genome-wide analyses identify transcription factors required for proper morphogenesis of Drosophila sensory neuron dendrites. Genes Dev 20:820-835. CrossRef Medline

Paxinos G, Franklin KB (2001) The mouse brain in stereotaxic coordinates 2nd ed. San Diego, CA: Academic Press.

Paxinos G, Watson C (2007) The rat brain in stereotaxic coordinates 6th ed. San Diego, CA: Academic Press.

Pfaffl MW (2001) A new mathematical model for relative quantification in real-time RT-PCR. Nucleic Acids Res 29:e45. CrossRef Medline

Pfaffl MW, Georgieva TM, Georgiev IP, Ontsouka E, Hageleit M, Blum JW (2002) Real-time RT-PCR quantification of insulin-like growth factor (IGF)-1, IGF-1 receptor, IGF-2, IGF-2 receptor, insulin receptor, growth hormone receptor, IGF-binding proteins 1, 2 and 3 in the bovine species. Domest Anim Endocrinol 22:91-102. CrossRef Medline

Pizzimenti CL, Navis TM, Lattal KM (2017) Persistent effects of acute stress on fear and drug-seeking in a novel model of the comorbidity between post-traumatic stress disorder and addiction. Learn Mem 24:422-431. CrossRef Medline

Pradhan A, Liu Y (2004) The calcium-responsive transactivator recruits CREB binding protein to nuclear bodies. Neurosci Lett 370:191-195. CrossRef Medline

Qiu Z, Ghosh A (2008) A calcium-dependent switch in a CREST-BRG1 complex regulates activity-dependent gene expression. Neuron 60:775787. CrossRef Medline

Renthal W, Maze I, Krishnan V, Covington HE 3rd, Xiao G, Kumar A, Russo
SJ, Graham A, Tsankova N, Kippin TE, Kerstetter KA, Neve RL, Haggarty SJ, McKinsey TA, Bassel-Duby R, Olson EN, Nestler EJ (2007) Histone deacetylase 5 epigenetically controls behavioral adaptations to chronic emotional stimuli. Neuron 56:517-529. CrossRef Medline

Renthal W, Kumar A, Xiao G, Wilkinson M, Covington HE 3rd, Maze I, Sikder D, Robison AJ, LaPlant Q, Dietz DM, Russo SJ, Vialou V, Chakravarty S, Kodadek TJ, Stack A, Kabbaj M, Nestler EJ (2009) Genomewide analysis of chromatin regulation by cocaine reveals a role for sirtuins. Neuron 62:335-348. CrossRef Medline

Rogge GA, Singh H, Dang R, Wood MA (2013) HDAC3 is a negative regulator of cocaine-context-associated memory formation. J Neurosci 33: 6623-6632. CrossRef Medline

Setlow B, Holland PC, Gallagher M (2002) Disconnection of the basolateral amygdala complex and nucleus accumbens impairs appetitive Pavlovian second-order conditioned responses. Behav Neurosci 116:267-275. CrossRef Medline

Staahl BT, Tang J, Wu W, Sun A, Gitler AD, Yoo AS, Crabtree GR (2013) Kinetic analysis of npBAF to $\mathrm{nBAF}$ switching reveals exchange of SS18 with CREST and integration with neural developmental pathways. J Neurosci 33:10348-10361. CrossRef Medline

Vogel-Ciernia A, Matheos DP, Barrett RM, Kramár EA, Azzawi S, Chen Y, Magnan CN, Zeller M, Sylvain A, Haettig J, Jia Y, Tran A, Dang R, Post RJ, Chabrier M, Babayan AH, Wu JI, Crabtree GR, Baldi P, Baram TZ, et al. (2013) The neuron-specific chromatin regulatory subunit BAF53b is necessary for synaptic plasticity and memory. Nat Neurosci 16:552-561. CrossRef Medline

Vogel Ciernia A, Kramár EA, Matheos DP, Havekes R, Hemstedt TJ, Magnan CN, Sakata K, Tran A, Azzawi S, López A, Dang R, Wang W, Trieu B, Tong J, Barrett RM, Post RJ, Baldi P, Abel T, Lynch G, Wood MA (2017) Mutation of neuron-specific chromatin remodeling subunit BAF53b: rescue of plasticity and memory by manipulating actin remodeling. Learn Mem 24:199-209. CrossRef Medline

White AO, Kramár EA, López AJ, Kwapis JL, Doan J, Saldana D, Davatolhagh MF, Alaghband Y, Blurton-Jones M, Matheos DP, Wood MA (2016) BDNF rescues BAF53b-dependent synaptic plasticity and cocaineassociated memory in the nucleus accumbens. Nat Commun 7:11725. CrossRef Medline

Wu JI, Lessard J, Olave IA, Qiu Z, Ghosh A, Graef IA, Crabtree GR (2007) Regulation of dendritic development by neuron-specific chromatin remodeling complexes. Neuron 56:94-108. CrossRef Medline

Yacubian J, Sommer T, Schroeder K, Gläscher J, Kalisch R, Leuenberger B, Braus DF, Büchel C (2007) Gene-gene interaction associated with neural reward sensitivity. Proc Natl Acad Sci U S A 104:8125-8130. CrossRef Medline 